\title{
Energy Intensity Determinants Based on Structure- oriented Cointegration by Embedding a Knowledge Box in a Time Series Model: Evidence From Iran
}

\author{
Parisa Esmaeili \\ Kharazmi University \\ Meysam Rafei ( $\sim$ m.rafei@khu.ac.ir) \\ Kharazmi University
}

\section{Research Article}

Keywords: Energy intensity, SVECM, DAG, PC algorithm, Cointegration, Energy policy

Posted Date: March 22nd, 2021

DOl: https://doi.org/10.21203/rs.3.rs-263118/v1

License: (c) (1) This work is licensed under a Creative Commons Attribution 4.0 International License.

Read Full License

Version of Record: A version of this preprint was published at Environmental Science and Pollution Research on September 30th, 2021. See the published version at https://doi.org/10.1007/s11356-02116099-0. 


\section{Energy Intensity Determinants Based on Structure-Oriented}

\section{Cointegration by Embedding a Knowledge Box in a Time Series}

3 Model: Evidence from Iran

\section{Parisa Esmaeilia, Meysam Rafei ${ }^{b^{*}}$}

${ }^{a}$ Faculty of Economics, Kharazmi University, Tehran, Iran.

ORCID ID: https://orcid.org/0000-0002-2778-1586

E-mail addresses: p.esmaeili34@gmail.com (P. Esmaeili)

${ }^{\mathrm{b}}$ Faculty of Economics, Kharazmi University, Tehran, Iran.

ORCID ID: https://orcid.org/0000-0002-9295-0307

\section{Abstract}

Energy intensity reduction is an exigent issue for Iran, where energy consumption is so high. Therefore, finding effective policies to reduce energy intensity is important. With this in mind, the impact of financial development, government investment, oil revenues, and trade openness on energy intensity is assessed in this study. We combined Structural Vector Error Correction Model (SVECM) and Directed Acyclic Graphs (DAG) technique to examine the relationships between study variables. The results of DAG prove that financial development, government investment, oil revenues, and trade openness influence the intensity of energy. Besides, the significant and long-run relationships among variables allowed us to apply SVECM. Impulse response functions and variance decomposition analysis indicate that government investment, oil revenues, and trade openness are negatively associated with the intensity of energy. Also, financial development positively influences energy intensity. Meanwhile, the impact of government investment is greater than oil revenues, trade openness, and financial development impacts. So, Government investment is the most effective policy regarding optimizing the consumption of energy and reducing energy intensity. We also advise policymakers to use oil revenues to increase government investment, enhancing the level of trade openness, and tax to the private sector to improve the level of energy intensity. 
24 Keywords: Energy intensity; SVECM; DAG; PC algorithm; Cointegration; Energy policy

\section{1. Introduction}

26

27

28

29

30

31

32

33

34

35

36

37

38

39

40

41

42

43

44

45

46

47

48

49

Energy, as one of the crucial inputs of production, which, along with other factors such as labor, capital, and raw materials, has a special place in the country's economic development (Mirzaei \& Bekri, 2017). The scarcity of energy resources in the world necessitates the efficient use of energy resources in the process of economic development (Pham et al., 2020; Zhu \& Lin, 2020). To optimize and improve the methods of resource exploitation, conversion and transfer of energy, and compare the situation of countries regarding energy consumption and the effectiveness of this factor on economic development, macro indicators of energy economy such as energy intensity are used. Energy intensity shows how much energy is used to produce a certain amount of GDP; thus, countries are trying to reduce energy intensity to lower energy conversion costs per unit of GDP, and this is one of the tangible goals of sustainable development (Samargandi, 2019; Zaidi et al., 2019). Currently, energy intensity is one of the strategic indicators in any country, which is used to examine the increase in energy efficiency both in terms of reducing energy dependence and in terms of climatic and environmental consequences of high energy consumption in the country (Pasierb et al., 1996; Sadorsky, 2013; Sun, 1998). Therefore, developed and developing countries are looking for factors that reduce their energy intensity and increase their energy efficiency.

Promoting the energy efficiency of countries requires efficient and extensive investment by the government or the private sector (Aller et al., 2018; Fu et al., 2013; Yanli Wang et al., 2020). In oil-exporting countries, oil revenues are one of the fundamental sources of government budgets (Breisinger et al., 2010). Therefore, these governments can achieve the desired results in reducing energy intensity by using oil revenues correctly in construction investments and improving technology. On the other hand, financial development is a factor that can affect private sector businesses, and by influencing production and energy consumption can affect energy intensity (Acheampong, 2019; Chen et al., 2019). Financial development can increase R\&D investments and enhances production by reducing uncertainty in investment (Tamazian et al., 2009). Besides, financial development can lead companies to use more advanced technology by reducing liquidity risk (Pan, Uddin, Han, et al., 2019). Therefore, financial development with the wealth effect and business effect can directly influence energy consumption (Sadorsky, 2010; Shahbaz \& Lean, 2012). Due to the competition in global markets, trade openness leads to domestic investment, so domestic firms are 
trying to increase productivity, improve technology, and promote innovation and thus reduce energy intensity

51 (Samargandi, 2019).

52 Given the concerns about energy consumption, numerous studies have discussed the intensity of energy. The scarcity 53 of energy resources and energy security, as well as environmental degradation and greenhouse gas emissions due to

54 increased energy consumption, are factors that highlight the need for studies of energy intensity and energy efficiency

55 (Zhu \& Lin, 2020). For this purpose, different approaches and methods of econometrics have been used. The Johansen 56 and Juselius (1990) method is one of the most decisive methods for examining long-run relationships between

57 variables. After determining the existence of long-run relationships between variables, the Vector Error Correction 58 Model (VECM) can be used. Economic considerations and theories are not taken into account in the VECM, but this 59 problem can be solved by using the Structural VECM (SVECM). Therefore, it is an attractive and efficient model to 60 study and analyze the factors affecting energy intensity.

61 Iran is one of the developing countries that have vast energy resources. Iran's energy consumption has been steadily 62 rising over the past decades, due to factors such as low energy prices and government subsidies (Hosseini Nasab et 63 al., 2012). The residential, industrial, and transportation sectors are the main consumers of energy in Iran, and the contribution of different energy-consuming sectors can be seen in Figure 1.

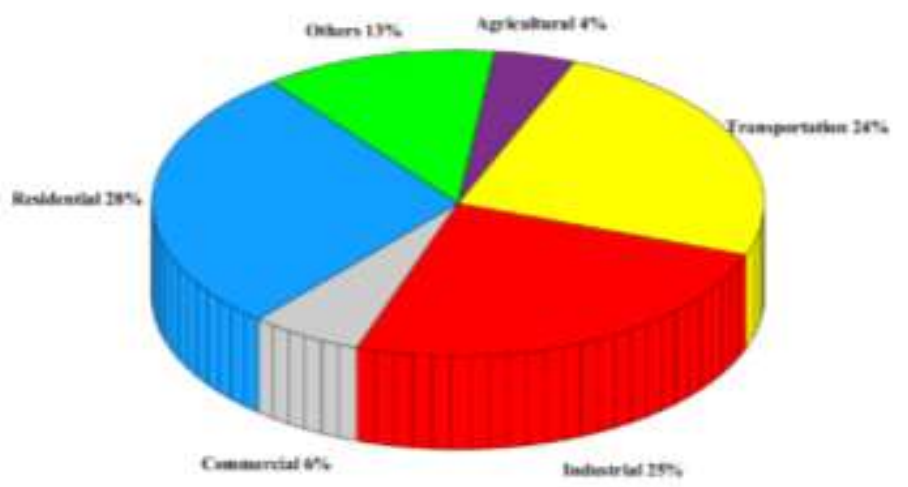

Figure 1 Contribution of different energy-consuming sectors in Iran 
Figure 2 shows that Iran does not have a favorable situation about the consumption of energy for goods and services.

71 Therefore, it has an inefficient energy consumption pattern and is a country with very high energy intensity. According

72 to Iran's energy Balance (2017), the energy intensity of Iran is not only higher than in developing countries and the

73 world, but it is also even higher than in oil-rich countries such as Venezuela and Saudi Arabia. Thus, to reduce the intensity of energy, corrective policies should be adopted, because, with this energy consumption's trend, Iran may be forced to import energy in the future.

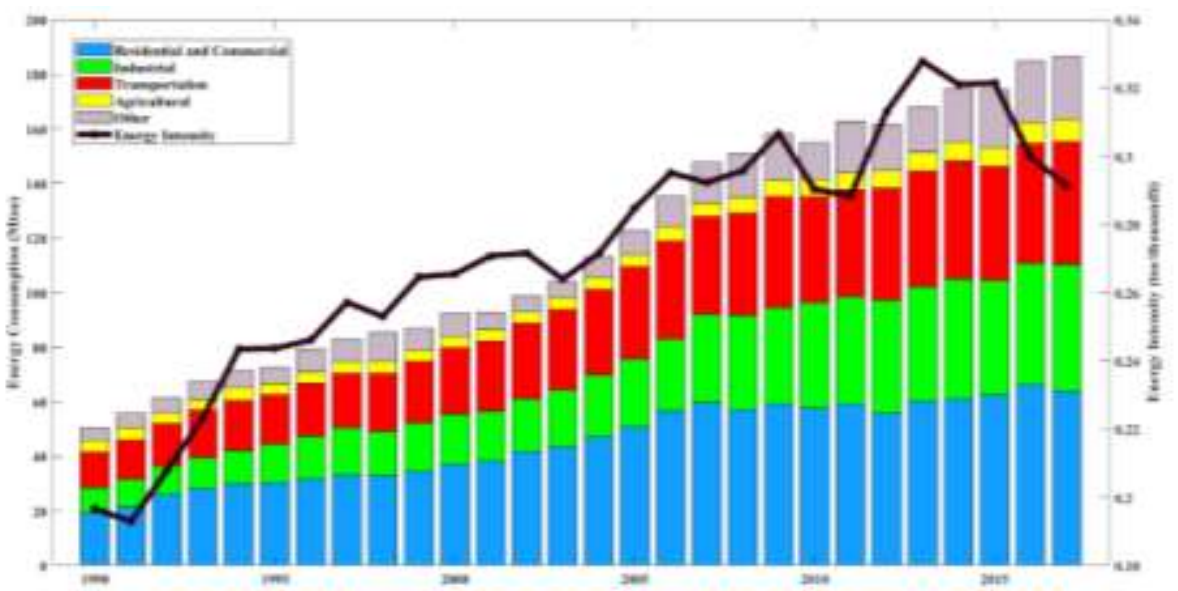

Figure 2 Energy consumption vs energy intensity

Source: Iran's energy balance (2017)

According to what stated above and the importance of improving energy efficiency, we intend to assess the factors that can reduce Iran's energy intensity. To this end, we consider evaluating the impact of four variables of government investments, oil revenues, financial development, and trade openness to reduce energy intensity. So, this study has been compiled in the following sections. After the introduction, the relevant literature on energy intensity discusses in Section 2; Section 3 explicates the Methodology and Data; Section 4 states the empirical results. The conclusions and policy implementation that are interpreted in Section 5.

\section{Literature review}

Various international organizations, such as the International Energy Agency and Economic and Social Council of the United Nations, have identified the energy intensity as one of the indicators of energy for sustainable development. Today, reducing the intensity of energy has become a vital issue for all countries in the world. Therefore, many researchers have studied the factors that affect energy intensity. In these studies, different variables are used such as 
trade openness, energy prices, foreign direct investment, technological innovations. Karanfil (2009) stated that

91 financial variables could be added to the energy consumption models to augment them. We will now examine the

92 results of some studies in this field.

93 Adom (2015) found that energy prices and foreign direct investment affected energy intensity significantly and

94 negatively, and also rising energy prices reduced the intensity of energy. Besides, structural changes increase energy

95 intensity. Du and Lei (2017) proved that technological progress, prices of energy, mix of energy, the structure of the

96 economy, and intensity of energy have a relationship in the long-run. Technological progress is the most important

97 factor in reducing the intensity of energy. Conversely, the prices of energy, energy mix, and technological progress

98 do not significantly reduce the intensity of energy in the short run. Aboagye (2017) concluded the existence of a long-

99 run relationship among the growth of economic and the intensity of energy. In the short-run, trade openness reduces

100 the intensity of energy. Besides, both urbanization and the intensity of energy affect each other. But the relationship

101 between industrialization and the intensity of energy is one-way. Finally, the absence of a relationship between the intensity of energy and foreign direct investment is proved.

Barkhordari and Fattahi (2017) found that energy prices, in the long run, affect the intensity of energy, and technological changes have a beneficial effect on the intensity of energy. Adom (2018) concluded that trade openness

105 leads to a decrease in the intensity of energy, while democracy leads to an increase in the intensity of energy. Bi et al.

106 (2019) realized that the impact of transportation infrastructure on the intensity of energy is significant and negative,

107 and this effect gradually becomes stronger. Deichmann et al. (2019) concluded that there is a negative correlation

108 between the growth of economic and the intensity of energy.

109 Pan, Uddin, Han, et al. (2019) realized the growth of economic impact is stronger on the intensity of energy in the 110 short-run. The impact of trade openness is growing over time. Technological innovations also improve the intensity 111 of energy. On the contrary, Samargandi (2019) concluded that technological innovation does not have a significant 112 effect on the intensity of energy. Besides, trade openness and energy price, reduce and increase the intensity of energy, 113 respectively. Rising energy prices, such as crude oil, will increase OPEC oil rents and increase their energy 114 consumption. Therefore, it leads to an increase in energy intensity. 
115 Chen et al. (2019) found that financial development in non-OECD countries reduced energy intensity, while in OECD

116 countries, it was statistically insignificant. Financial development in non-OECD countries first reduces the intensity

117 of energy and then increase it. Thus, the relationship between them is U-shaped. He and Huang (2019) concluded that

118 investment, population, enterprise size, and urbanization decrease the intensity of energy, while policy instruments

119 and industrial structure increase it. Cao et al. (2020) found that foreign direct investment has an insignificant effect on

120 the intensity of energy. Table 1 describes the details of these studies.

121

122 Table 1

123 Literature review: energy intensity determinants

\begin{tabular}{|c|c|c|c|c|c|}
\hline Authors & Period & Country & Methodology & $\begin{array}{l}\text { Focused } \\
\text { variables on } \\
\text { energy } \\
\text { intensity }\end{array}$ & Results \\
\hline $\begin{array}{l}\text { Adom } \\
(2015)\end{array}$ & $\begin{array}{l}1971- \\
2011\end{array}$ & Nigeria & $\begin{array}{l}\text { Fully } \\
\text { modified } \\
\text { OLS }\end{array}$ & $\begin{array}{l}\text { Energy price, } \\
\text { Foreign direct, } \\
\text { Industry } \\
\text { structure }\end{array}$ & $\begin{array}{l}\text { The effect of energy price on energy intensity is } \\
\text { negative and significant. The effect of foreign } \\
\text { direct inflows on energy intensity is negative and } \\
\text { significant. The relationship between industry } \\
\text { structure and energy intensity is significantly } \\
\text { positive. }\end{array}$ \\
\hline $\begin{array}{l}\text { Du and Lei } \\
\text { (2017) }\end{array}$ & $\begin{array}{l}1985- \\
2014\end{array}$ & China & $\begin{array}{l}\text { ARDL } \\
\text { bounds } \\
\text { approach, } \\
\text { VECM }\end{array}$ & $\begin{array}{l}\text { Energy price, } \\
\text { Technological } \\
\text { progress, } \\
\text { Economic } \\
\text { structure, } \\
\text { Energy mix }\end{array}$ & $\begin{array}{l}\text { The long-run relationship between energy price, } \\
\text { technological progress, economic structure, energy } \\
\text { mix, and energy intensity. }\end{array}$ \\
\hline $\begin{array}{l}\text { Aboagye } \\
(2017)\end{array}$ & $\begin{array}{l}\text { 1981- } \\
2014\end{array}$ & Ghana & ARDL & $\begin{array}{l}\text { Economic } \\
\text { growth, Trade } \\
\text { openness }\end{array}$ & $\begin{array}{l}\text { The long-run relationship between economic } \\
\text { growth and energy intensity. Trade openness } \\
\text { reduces energy intensity. }\end{array}$ \\
\hline
\end{tabular}




\begin{tabular}{|c|c|c|c|c|c|}
\hline $\begin{array}{l}\text { Barkhordari } \\
\text { and Fattahi } \\
\text { (2017) }\end{array}$ & $\begin{array}{l}1986- \\
2015\end{array}$ & Iran & ARDL & $\begin{array}{l}\text { Energy prices, } \\
\text { Technological } \\
\text { improvement }\end{array}$ & $\begin{array}{l}\text { There is a long-run relationship between energy } \\
\text { prices and energy intensity. Technology changes } \\
\text { have a constructive impact on energy intensity in } \\
\text { Iran's industry. }\end{array}$ \\
\hline $\begin{array}{l}\text { Adom } \\
(2018)\end{array}$ & $\begin{array}{l}1970- \\
2016\end{array}$ & Ghana & $\begin{array}{l}\text { Stock- } \\
\text { Watson } \\
\text { dynamic OLS }\end{array}$ & $\begin{array}{l}\text { Trade } \\
\text { openness, } \\
\text { political } \\
\text { regimes }\end{array}$ & $\begin{array}{l}\text { Trade openness reduces energy intensity. } \\
\text { Democracy increases energy intensity. }\end{array}$ \\
\hline $\begin{array}{l}\text { Bi et al. } \\
(2019)\end{array}$ & $\begin{array}{l}2001- \\
2016\end{array}$ & China & $\begin{array}{l}\text { Panel smooth } \\
\text { transition } \\
\text { regression }\end{array}$ & $\begin{array}{l}\text { Public } \\
\text { infrastructure }\end{array}$ & $\begin{array}{l}\text { Public infrastructure influences energy intensity, } \\
\text { which plays an important role in strategies related } \\
\text { to energy. }\end{array}$ \\
\hline $\begin{array}{l}\text { Deichmann } \\
\text { et al. (2019) }\end{array}$ & $\begin{array}{l}1990- \\
2014\end{array}$ & $\begin{array}{l}137 \\
\text { countries }\end{array}$ & $\begin{array}{l}\text { Flexible } \\
\text { piecewise } \\
\text { linear } \\
\text { regression } \\
\text { model }\end{array}$ & $\begin{array}{l}\text { Economic } \\
\text { growth }\end{array}$ & $\begin{array}{l}\text { There is a negative correlation between GDP per } \\
\text { capita and energy intensity. }\end{array}$ \\
\hline $\begin{array}{l}\text { Pan, Uddin, } \\
\text { Han, et al. } \\
\text { (2019) }\end{array}$ & $\begin{array}{l}1976- \\
2014\end{array}$ & Bangladesh & $\begin{array}{l}\text { DAG } \\
\text { technique, } \\
\text { SVAR }\end{array}$ & $\begin{array}{l}\text { Financial } \\
\text { development, } \\
\text { Trade } \\
\text { openness, } \\
\text { technological } \\
\text { innovation, } \\
\text { economic } \\
\text { growth }\end{array}$ & $\begin{array}{l}\text { The impact of economic growth on energy } \\
\text { intensity in the short-run is greater. The effect of } \\
\text { trade openness on energy intensity increases over } \\
\text { time. Technological innovation has a key role in } \\
\text { promoting energy intensity where it is influenced } \\
\text { by financial development and trade openness. }\end{array}$ \\
\hline $\begin{array}{l}\text { Samargandi } \\
(2019)\end{array}$ & $\begin{array}{l}1990- \\
2016\end{array}$ & $\begin{array}{l}\text { OPEC } \\
\text { countries }\end{array}$ & Panel ARDL & $\begin{array}{l}\text { Trade } \\
\text { openness, } \\
\text { Technological } \\
\text { innovation, } \\
\text { energy price }\end{array}$ & $\begin{array}{l}\text { Trade openness reduces energy intensity, while } \\
\text { energy price increases energy intensity. } \\
\text { Technological innovation has an insignificant role } \\
\text { in minimizing energy intensity. }\end{array}$ \\
\hline
\end{tabular}




\begin{tabular}{|c|c|c|c|c|c|}
\hline \multirow[t]{2}{*}{ Chen et al. } & $\begin{array}{l}1990- \\
2014\end{array}$ & $\begin{array}{l}21 \text { OECD } \\
\text { countries }\end{array}$ & $\begin{array}{l}\text { Two-way } \\
\text { fixed-effects } \\
\text { model }\end{array}$ & $\begin{array}{l}\text { Financial } \\
\text { development }\end{array}$ & $\begin{array}{l}\text { The effect of financial development on energy } \\
\text { intensity is not statistically different from zero in } \\
\text { all specifications. }\end{array}$ \\
\hline & & $\begin{array}{l}77 \text { non- } \\
\text { OECD } \\
\text { countries }\end{array}$ & & & Financial development reduces energy intensity. \\
\hline $\begin{array}{l}\text { He and } \\
\text { Huang } \\
\text { (2019) }\end{array}$ & $\begin{array}{l}2006- \\
2015\end{array}$ & China & $\begin{array}{l}\text { Dynamic } \\
\text { optimal } \\
\text { theoretical } \\
\text { framework }\end{array}$ & $\begin{array}{l}\text { Population, } \\
\text { Investment, } \\
\text { Urbanization, } \\
\text { Industrial } \\
\text { structure, } \\
\text { Policy } \\
\text { instrument, } \\
\text { Enterprise size }\end{array}$ & $\begin{array}{l}\text { Population, investment, urbanization, and } \\
\text { enterprise size decrease energy intensity, but } \\
\text { industrial structure and policy instrument drive it } \\
\text { up. }\end{array}$ \\
\hline $\begin{array}{l}\text { Cao et al. } \\
(2020)\end{array}$ & $\begin{array}{l}1990- \\
2014\end{array}$ & $\begin{array}{l}\text { Emerging } \\
\text { country }\end{array}$ & $\begin{array}{l}\text { Panel } \\
\text { regression } \\
\text { model, Panel } \\
\text { smooth } \\
\text { transition } \\
\text { regression } \\
\text { model }\end{array}$ & $\begin{array}{l}\text { Foreign direct } \\
\text { investment }\end{array}$ & $\begin{array}{l}\text { FDI exerts an insignificant impact on energy } \\
\text { intensity. }\end{array}$ \\
\hline
\end{tabular}

124 Source: Current Research

125 Many studies have been conducted on Iran's energy intensity, and many of these studies have examined the factors

126 that reduce the energy intensity of Iran. In some of these studies, the variables of trade openness and financial

127 development have been identified as effective variables in reducing energy intensity. Because Iran is an oil exporter

128 country and oil revenues have a significant impact on Iran's economy, it has always been recognized as a vital variable

129 in the Iranian economy. The government sector in Iran's economy is very large, so government investment plays a

130 major role in various sectors of Iran. Therefore, in this study, we intend to examine the impact of financial

131 development, government investment, oil revenues, and trade openness on Iran's energy intensity in a multivariate 132 framework. 


\section{Methodology and Data}

Vector Autoregressive (VAR) models are widely used after Sims (1980) critique of simultaneous equations. These models have become useful tools in macroeconomic studies and have been widely used to investigate the relationship between variable innovations. SVECM can use when the data is not stationary at the level and the cointegration test indicates the presence of a cointegration vector. The SVECM identifies structural shocks based on economic theory (Nizamani et al., 2017).

The SVECM has been developed by King et al. (1991), which considered only long-run restrictions beyond its model. While Breitung et al. (2004) expanded the SVECM to include both long-run and short-run restrictions (Ivrendi \&

141 Guloglu, 2010).

142 The $\rho$ order of SVECM is as follows:

$$
A \Delta y_{t}=\Pi^{*} y_{t-1}+\Gamma_{1}^{*} \Delta y_{t-1}+\ldots+\Gamma_{\rho-1}^{*} \Delta y_{t-\rho+1}+B \varepsilon_{t}
$$

145 of $y_{t}=\left(y_{1 t}, \ldots, y_{K t}\right)$ shows endogenous variables, $\Pi^{*}$ is the coefficient matrix, $\Gamma_{i}^{*}(j=1, \ldots, \rho-1)$

146 displays the parameters of structural form, and is a $(K \times K)$ matrix. $\mathcal{E}_{t}$ is a $(K \times 1)$ white noise error terms of 147 structural form vector with zero mean, and they aren't correlated serially and matrix of variance-covariance is $\Omega$ 148 (Nizamani et al., 2017).

149 Multiplying Eq. (1) by $A^{-1}$, the reduced form can obtain.

$$
\Delta y_{t}=A^{-1} \Pi^{*} y_{t-1}+A^{-1} \Gamma_{1}^{*} \Delta y_{t-1}+\ldots+A^{-1} \Gamma_{\rho-1}^{*} \Delta y_{t-\rho+1}+A^{-1} B \varepsilon_{t}
$$

$$
\Delta y_{t}=\Gamma y_{t-1}+\Gamma_{1} \Delta y_{t-1}+\ldots+\Gamma_{\rho-1} \Delta y_{t-\rho+1}+u_{t}
$$


152 Where $\Pi=A^{-1} \Pi^{*}, \Gamma_{j}=A^{-1} \Gamma_{j}^{*}$ and $u_{t}=A^{-1} B \varepsilon_{t}$.

153 Assuming all variables are stationary at the first difference, the reduced form of VECM in Eq. (2)

can be

154 rewritten as follows:

155

$$
\Delta y_{t}=\alpha \beta^{\prime} y_{t-1}+\Gamma_{1} \Delta y_{t-1}+\ldots+\Gamma_{\rho-1} \Delta y_{t-\rho+1}+u_{t}
$$

156 Where $y_{t}$ is observable variables' vector, $\alpha$ represents the $(K \times r)$ loading coefficients matrix and $\beta$ is the $157(K \times r)$ matrix of cointegration. Here $\mathrm{r}$ is the number of cointegration relationships between the variables. The

$158 \alpha \beta y_{t-1}$ is related to the error correction term. The $u_{t}$ is a white noise error with zero mean and the matrix of 159 variance-covariance $\sum_{u} A^{-1} \Omega\left(A^{-1}\right)$.

160 As Johansen (1995) stated, by using Granger Representation Theorem (GRT), the structural model can be write as the 161 Moving Average (MA) representation of Beveridge-Nelson decomposition of $y_{t}$ as follows:

$162 \quad y_{t}=\Xi \sum_{i=1}^{t} \boldsymbol{u}_{i}+\Xi^{*}(L) \boldsymbol{u}_{t}+y_{0}^{*}$

It decomposes $y_{t}$ into two parts $\mathrm{I}(0)$ and $\mathrm{I}(1)$. Matrix $\Xi$ represents the effects of shocks in the long-run and includes

164 the $K=n-r$ components of $\mathrm{I}(1)$ in $y_{t}$. (Boufateh et al., 2013). Matrix $\Xi$ is shown as follows:

$165 \quad \Xi=\beta_{\perp}\left(\alpha_{\perp}^{\prime}\left(I_{K}-\sum_{i=1}^{\rho-1} \Gamma_{i}\right) \beta_{\perp}\right)^{-1} \alpha_{\perp}^{\prime}$

$166 \Xi^{*}(L) \boldsymbol{U}_{t}$ is the matrix of transitory effects and includes $\mathrm{r}$ components of $\mathrm{I}(0)$ in $y_{t}$ and is polynomial of infinite-

167 order in the lag operator with $\Xi_{j}^{*}$ the matrix that $\lim _{j \rightarrow \infty} \Xi^{*}=0$ (Bonga-Bonga \& Kabundi, 2015; Boufateh et al., 
168 2013). $\quad \Xi^{*}(L) \quad$ Matrix $\quad$ is $\quad$ shown follows:

$169 \quad \Xi^{*}(L)=\sum_{j=0}^{\infty} \Xi_{j}^{*} L^{j}$

170 It is worth noting that if the system's cointegrating rank is $\mathrm{r}$, the $\Xi$ has to rank $\boldsymbol{K}-\boldsymbol{r}$. Whereas $\boldsymbol{\Xi}_{j}^{*}$ 's has

171 transitory effects, it shows forecast error impulse responses long-run effects. $y_{0}^{*}$ includes all initial values.

172 The restriction must impose on matrices A and B to identify the structural form from the reduced form. Since the main

173 focus of this research is on residuals, B-model is commonly used to identify structural innovations, and matrix A

174 considered as an identity matrix. As a result, the restrictions imposed on matrix B.

$175 \quad u_{t}=B \mathcal{E}_{t}$ with $\varepsilon_{t}:\left(0, I_{K}\right)$

176 By placing Eq. (7) in Eq. (4), the following equation will be obtained:

$177 \quad \boldsymbol{y}_{t}=\Xi \sum_{i=1}^{t} B \mathcal{E}_{i}+\sum_{j=0}^{\infty} \Xi_{j}^{*} \boldsymbol{u}_{t-j}+\boldsymbol{y}_{\mathrm{o}}^{*}$

$178 \boldsymbol{y}_{t}=\Xi B \sum_{i=1}^{t} \varepsilon_{i}+\sum_{j=0}^{\infty} \Xi_{j}^{*} \boldsymbol{u}_{t-j}+\boldsymbol{y}_{\mathrm{o}}^{*}$

$179 \mathrm{~B}$ and $\Xi B$ represent the short-run and long-run effects of structural innovations, respectively. At most $\mathrm{r}$ columns of 180 the matrix $\Xi B$ must be zero. In other words, Structural innovations can have $\mathrm{r}$ and $K-r$ transitory and permanent 181 effects, respectively. The $\Xi B$ matrix's rank is $K-r$, every zero columns are only $K-r$ independent restrictions. 182 Therefore, the $\mathrm{r}$ zero columns demonstrate only $r(K-r)$ independent restrictions.

183 In model B, $\frac{K(K-1)}{2}$ restrictions are required for local just-identify structural innovations. Based on the structure 184 of the model cointegration, there are $r(K-r)$ independent restrictions. Therefore, to accurately just-identify 
185 structural innovations, $\frac{K(K-1)}{2}-r(K-r)$ additional restrictions are required, which must be imposed on B and $186 \Xi B$ matrices based on the structure of economics and theory. $\frac{r(r-1)}{2}$ are for transitory effects and must be imposed 187 on matrix B, and $\frac{(K-r)((K-r)-1)}{2}$ are for permanent effects and must be imposed on matrix $\Xi B$ (Lütkepohl, 188 2005).

189 To determine these zero restrictions, we intend to use the causal relationship between variables and economic theories. 190 In most previous studies, the Granger (1969) causality method has been used to discover the causal relationship 191 among variables, which does not show the real causal relationship (Bessler \& Yang, 2003). Pearl (2000); Spirtes et al. 192 (2000); Demiralp and Hoover (2003) introduced the DAG technique in their studies to identify the causal relationship 193 among economic variables contemporaneously.

194 In this paper, the DAG technique is chosen to explore the simultaneous causal relationship between the study variables. 195 In DAG, arrows indicate the causal relationship between two variables. Thus, the absence of an edge between $\mathrm{X}$ and 196 Y (X Y) exhibits the lack of a causal relationship between them. If there is a covariance between the two variables but 197 there is no causal relationship between them, it is displayed with an edge without direction $(\mathrm{Y}-\mathrm{X})$. Also, the one198 sided edge $(\mathrm{X} \rightarrow \mathrm{Y}$ ) demonstrates that the causal relationship is from $\mathrm{Y}$ to $\mathrm{X}$, and $\mathrm{Y}$ causes $\mathrm{X}$. Finally, two-sided 199 edge $(\mathrm{Y} \leftrightarrow \mathrm{X})$ indicates the simultaneous effect of $\mathrm{X}$ and $\mathrm{Y}$ on each other (Pan, Ai, et al., 2019).

200 In the Tetrad program, the PC algorithm introduced by Peter and Clark can be used to directed graphs (Spirtes et al., 201 2000). This algorithm seeks to eliminate edges and apply causal flows between variables. Therefore, this algorithm 202 initially only connects variables with a line called edges that are directionless (Miljkovic et al., 2016). Then, by the 203 implementation of the correlation test, it removes the edges between the two variables in the absence of correlation 204 base on vanishing a correlation of zero-order or partial correlation of high-order (Yang \& Bessler, 2008). subsequently, 205 between a pair of variables' correlation conditional on the third variable for the remaining edges is checked. Based on 206 the PC algorithm, the edges between variables that have a conditional correlation of zero from the first order are 207 removed. If $\mathrm{N}$ variables exist, the PC algorithm examines the conditional correlation up to N-2 order between the 208 variables (Pan, Uddin, Han, et al., 2019). 
209 Conditional variables on the edges eliminated between every two variables are called separate sets whose edges have 210 been eliminated. If an edge is removed by considering the unconditional correlation, it will have a separate empty set.

211 Finally, the edges that remain can be oriented according to the steps of the PC algorithm by using a separate set.

212 Videlicet, Suppose X $-\mathrm{Y}-\mathrm{Z}$ pattern, $\mathrm{X}$ and $\mathrm{Y}$ are next together and like Z and Y. They are called adjacent, But 213 the variables of $\mathrm{Z}$ and $\mathrm{X}$ don't consider as adjacent. Thus, if $\mathrm{Y}$ is not in the $\mathrm{X}$ and $\mathrm{Z}$ separate set, the mentioned pattern 214 can show as $\mathrm{X} \rightarrow \mathrm{Y} \leftarrow \mathrm{Z}(\mathrm{Ji}$ et al., 2018).

215 The statistic of Fisher's $\mathrm{z}$ in the PC algorithm is for testing the correlations and conditional correlation of estimated 216 sample against zero (Bessler \& Yang, 2003; Z. Wang et al., 2007; Yang et al., 2006). The mentioned test statistic is 217 displayed as follows:

$$
z[\rho(i, j \mid k) n]=\left[\frac{1}{2} \sqrt{(n-|k|-3)}\right] \times \ln \left\{\frac{|1+\rho(i, j \mid k)|}{1-\rho(i, j \mid k)}\right\}
$$

219 Where n shows the observation's number in the correlation estimation, $\rho(i, j \mid k)$ represents the $\mathrm{i}$ and $\mathrm{j}$ correlation of 220 population conditional on $\mathrm{k},|k|$ declare variables number in $\mathrm{k} . z[\rho(i, j \mid k) n]-z[r(i, j \mid k) n]$ distributed normally,

221 If the distribution of $\mathrm{i}, \mathrm{j}$, and $\mathrm{k}$ are normal and $r(i, j \mid k)$ represents the $\mathrm{i}$ and $\mathrm{j}$ sample correlation conditional on $\mathrm{k}$

222 (Pan, Uddin, Han, et al., 2019).

223 The test of likelihood ratio introduced by Sims (1980) is for testing the DAG identifying restrictions for over-

224 identification. The $T\left[\log (\operatorname{det}(\Omega))-\log \left(\operatorname{det}\left(\sum\right)\right)\right]$ test statistic is obtained from the equation Aet $=v t$ and its

225 purpose is to investigate the relationship between the restrictions of the observed shocks (et) parameter and 226 orthogonal shocks $(v t)$.

227 The distribution of this statistic is chi-squared and T represents observations' number, log declares transformation in 228 the form of logarithmic, det represents the operator of the determinant, $\Omega$ is the matrix of variance-covariance that 
229 obtained from the restrictions of the A-matrix, and $\sum$ is the matrix of variance-covariance that obtained from the 230 observed non-orthogonal shocks (Pan, Uddin, Han, et al., 2019; Yang et al., 2006).

\section{Data}

232 In this study, we examine the impact of four economic variables, including financial development, trade openness, 233 government investment, and oil revenues, on energy intensity during the years 1967 to 2017 . Various proxies for

234 financial development have been used in studies such as domestic credit to private sector to GDP ratio, stock market 235 capitalization to GDP ratio, and so on (Pan, Uddin, Saima, et al., 2019). Here, following the Kahouli (2017); Pan, 236 Uddin, Han, et al. (2019), and Gómez and Rodríguez (2019), we used the domestic credit to the private sector to GDP 237 ratio as a proxy for the financial development. We extracted this data from GFDD (2019). To calculate the trade 238 openness, following to You Wang and Gong (2020), we used the sum of exports and imports to GDP, which shows 239 the level of openness of trade and received the data from WDI (2019). We also got government investment and oil 240 revenues data from WDI (2019) and OPEC (2020), respectively. To calculate the energy intensity, we obtained the 241 ratio of energy consumption to GDP and collected energy consumption and GDP data from Iran's Energy Balance 242 (2017) and WDI (2019), respectively.

243 We got the idea to select these variables from Pan, Uddin, Han, et al. (2019) study, which dealt with the relationship 244 between trade openness and financial development with energy intensity. We chose oil revenues because the results 245 of Yildirim et al. (2020) study showed that oil revenues have a significant impact on financial development and it also 246 plays a key role in the economies of OPEC member countries. Finally, the relationship between oil revenues and 247 government investment became apparent in Rodríguez (2020) study. So, we also chose government investment, and 248 we want to examine whether these variables can affect the energy intensity or not. All variables are converted to 249 natural logarithms. Our data vector $y_{t}=(\operatorname{LnFD}, \mathrm{LnEI}, \mathrm{LnIG}, \mathrm{LnOR}, \mathrm{LnTO})^{\prime}$ includes the variables of 250 Financial development (LnFD), energy intensity (LnEI), government investment (LnIG), oil revenues (LnOR), and 251 trade openness (LnTO). 


\section{4. Empirical results}

253 In the first step, we examined the descriptive statistics of the data, the result of which are shown in Table 2. The results

254 show that energy intensity in 1972 and 2013 had its lowest and highest values, respectively.

255 
Table 2

257 Descriptive statistics

\begin{tabular}{lccccc}
\hline \hline & LnFD & LnTO & LnIG & LnOR & LnEI \\
\hline \hline Mean & 3.293045 & 3.707798 & 2.302124 & 2.797593 & -1.809532 \\
Median & 3.122736 & 3.756674 & 2.265135 & 2.775334 & -1.538968 \\
Maximum & 4.277790 & 4.332254 & 3.214681 & 3.899781 & -1.115471 \\
Minimum & 2.719780 & 2.649351 & 1.565133 & 1.878437 & -3.179542 \\
Standard deviation & 0.428362 & 0.308446 & 0.368839 & 0.443454 & 0.699122 \\
Skewness & 0.791809 & -1.126675 & 0.269276 & 0.246752 & -0.941260 \\
Kurtosis & 2.322628 & 5.391107 & 2.789296 & 2.884716 & 2.323694 \\
Jarque-Bera & 6.304194 & 22.93934 & 0.710674 & 0.545776 & 8.502702 \\
Probability & 0.042762 & 0.000010 & 0.700937 & 0.761178 & 0.014245 \\
Observations & 51 & 51 & 51 & 51 & 51 \\
\hline \hline
\end{tabular}

258 Source: Estimation Result

259 Table 3 shows the strength of the correlation between variables. The results show that the correlation between energy

260 intensity and other variables is high, and it has a positive correlation with financial development and a negative 261 correlation with trade openness, government investment, and oil revenues. 
Table 3

Correlation matrix

\begin{tabular}{clllll}
\hline \hline & LnFD & LnTO & LnIG & LnOR & LnEI \\
\hline \hline Ln DF & 1 & & & & \\
Ln TO & 0.2713 & 1 & & & \\
Ln IG & -0.5660 & 0.2472 & 1 & & \\
Ln OR & -0.2266 & 0.6796 & 0.5554 & 1 & \\
Ln EI & 0.5590 & -0.2044 & -0.7549 & -0.6191 & 1 \\
\hline \hline
\end{tabular}

267 Stationary has particular importance in the study of time-series data, as non-stationary behaviors such as random walk,

268 trend or cycles cause unusual regressions (Benjamin \& Lin, 2020; Pan, Uddin, Han, et al., 2019). Therefore, we used

269 two unit root tests of Augmented Dickey and Fuller (1979) and Phillips and Perron (1988) to check the stationary of

270 the data. MacKinnon (1996) p-values of one-sided are used in the test of Augmented Dickey-Fuller for critical values.

271 Newey-West using Barlett kernel specifies the Phillips-Perron test bandwidth (Pan, Uddin, Saima, et al., 2019). Table

2724 demonstrates the results of the Augmented Dickey-Fuller and Phillips-Perron tests. In these two tests, the existence

273 of a unit root is its null hypothesis. According to Augmented Dickey-Fuller and Phillips-Perron tests, the variables of

274 financial development, government investment, oil revenues, and energy intensity are I(1).

275 Although Augmented Dickey-Fuller test results show trade openness is stationary at the level at a 10\% significance

276 level, it is non-stationary at other significance levels, so we consider it I(1). The results of the Phillips-Perron test

277 prove that trade openness is $\mathrm{I}(1)$. 
Table 4

279 Unit root test

\begin{tabular}{|c|c|c|c|c|c|c|}
\hline \multirow[t]{2}{*}{ Variables } & \multirow[t]{2}{*}{ Equation includes } & \multicolumn{2}{|l|}{$\mathrm{ADF}$} & \multicolumn{2}{|l|}{$\mathrm{PP}$} & \multirow[t]{2}{*}{ Remarks } \\
\hline & & level & First diff. & Level & First diff. & \\
\hline \multirow[t]{2}{*}{$\overline{L n F D}$} & Intercept & 0.2624 & $-6.1084^{* * *}$ & 0.1576 & $-6.1186^{* * * *}$ & $\mathrm{I}(1)$ \\
\hline & Intercept and trend & -1.3556 & $-6.2654^{* * *}$ & -1.2905 & $-6.2455^{* * *}$ & \\
\hline \multirow[t]{2}{*}{ Ln TO } & Intercept & $-2.5772^{*}$ & $-4.8057^{* * *}$ & -2.2632 & $-4.8057^{* * * *}$ & $\mathrm{I}(0) / \mathrm{I}(1)$ \\
\hline & Intercept and trend & -2.5630 & $-4.7547^{* * *}$ & -2.2582 & $-4.7547^{* * *}$ & \\
\hline \multirow[t]{2}{*}{ Ln IG } & Intercept & -1.6449 & $-7.1953^{* * * *}$ & -1.6679 & $-7.2245^{* * *}$ & $\mathrm{I}(1)$ \\
\hline & Intercept and trend & -3.0547 & $-7.1158^{* * * *}$ & -3.1488 & $-7.1395^{* * *}$ & \\
\hline \multirow[t]{2}{*}{ Ln OR } & Intercept & -2.5007 & $-8.3712^{* * * *}$ & -2.4085 & $-8.4934^{* * *}$ & $\mathrm{I}(1)$ \\
\hline & Intercept and trend & -2.7359 & $-8.2822^{* * *}$ & -2.6706 & $-8.3990^{* * *}$ & \\
\hline \multirow[t]{2}{*}{ Ln EI } & Intercept & -2.3189 & $-4.3656^{* * *}$ & -1.6811 & $-4.3656^{* * *}$ & $\mathrm{I}(1)$ \\
\hline & Intercept and trend & -0.8609 & $-4.4486^{* * *}$ & -0.5460 & $-4.6046^{* * *}$ & \\
\hline
\end{tabular}

Notes: $*, * *, * * *$ denote statistically significant at the $10 \%, 5 \%$, and $1 \%$ levels, respectively.

Source: Estimation Result

283 Since all variables at the first difference are stationary and also integrated of order one, we are allowed to use the test

284 of cointegration. The test of cointegration shows the presence of a long-run relationship between variables, for which

285 we must first determine the optimal lag. The optimal lag selected by the Schwarz Information Criterion (SIC) and

286 Akaike Information Criterion (AIC) is lag one. After determining the optimal lag and estimating the VAR model of

287 order one, we applied the Johansen and Juselius (1990) cointegration test to check the existence and order of

288 cointegration.

289 Trace and Maximum Eigenvalue statistics are used to examine this test, the results of which are represented in Table

2905 . The null hypothesis of zero cointegration equation is rejected at the 5\%. Therefore, the results recommend the

291 existence of one cointegration equilibrium relationship between financial development, trade openness, government 
292 investment, oil revenues, and energy intensity. Consequently, VECM is the appropriate method for this study

293 (Hasanov, 2020; Taghizadeh-Hesary et al., 2020).

294 Table 5

295 Results of Johansen cointegration rank test

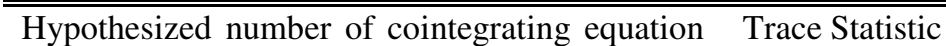

Maximum Eigenvalue Statistic

(s)

None

$37.36754 * * 24530 * *$

At most 1

38.12224

21.76259

Notes: *,**,*** denote statistically significant at the 10\%, 5\%, and 1\% levels, respectively.

297 Source: Estimation Result

Since VECM cannot consider the structures of the economy, we intend to use the SVECM (The results of the VECM estimate can be seen in Appendix A). As discussed in the methodology, we have to impose restrictions on matrices A,

$\mathrm{B}$, and $\Xi B$. In B-model to identify the structural innovations, we consider $\mathrm{A}$ as $I_{5}$ and impose restrictions on matrix

$\mathrm{B}$ and $\Xi B$.

$$
B=\left[\begin{array}{lllll}
* & * & * & * & * \\
* & * & * & * & * \\
* & * & * & * & * \\
* & * & * & * & * \\
* & * & * & * & *
\end{array}\right]
$$$$
\Xi B=\left[\begin{array}{lllll}
* & * & * & * & * \\
* & * & * & * & * \\
* & * & * & * & * \\
* & * & * & * & * \\
* & * & * & * & *
\end{array}\right]
$$

304 Given that $K=5$, we need $\frac{5(5-1)}{2}=10$ independent restrictions for local just-identify structural innovations.

305 Since the result show that $r=1$ we must set a column of matrix $\Xi B$ to zero, and consider this column as

$3061(5-1)=4$ independent restrictions. Now 6 remaining restrictions must be imposed on matrices B and $\Xi B$. Since

307 the identification of transitory shocks requires $\frac{1(1-1)}{2}=0$ restrictions, matrix B is already identified in this model

308 and no restrictions are imposed on matrix B. Therefore, all of these 6 zero restrictions must be imposed on the matrix $309 \Xi B$. 
310 It is common for researchers to turn to economic theories and previous studies to determine which elements of these

311 matrices should be imposed. It is noteworthy that previous studies have different results depending on the period and

312 countries that were selected. But we are looking for a gateway to apply relevant data in addition to previous studies

313 and economic theories. Therefore, we intend to use the DAG technique, in which, in addition to data of studies, the

314 results of previous studies can be added to the knowledge box and more accurate results can be achieved.

315 As mentioned, DAG analysis is an effective way to find contemporary causal flows between variables. Hence, we 316 used this method to explore the contemporaneous causal relationship between the variables of financial development,

317 trade openness, government investment, oil revenues, and energy intensity. To obtain the DAG graph, we loaded the 318 data into the Tetrad program and applied the PC algorithm to it. The PC algorithm first binds all the variables together 319 and then removes edges according to the correlation or partial correlation at the significance level we predefined. 320 Spirtes et al. (2000) stated that this level of significance should be determined based on the number of observations.

321 Thus, for samples with less than 100 observations, a significance level of $20 \%$ was suggested. For samples with 100 322 to 300 observations, a significance level of $10 \%$ was suggested, and for very large samples with more observations, a 323 significance level of $5 \%$ or $1 \%$ was recommended.

324 We also defined a knowledge box in which we used the results of studies dealing with the relationship between the 325 variables of financial development, trade openness, government investment, oil revenues, and energy intensity (such 326 as, Khan et al. (2020); Y1ldırım et al. (2020), Adom (2019); Erdogan (2020); Hossain and Mitra (2013); Pan, Uddin, 327 Han, et al. (2019), etc.). Then, we used the likelihood ratio test to identify the over-identification of the restrictions, 
328 and the p-value of $29 \%$ showed that the restrictions were applied correctly and matched the data. The result of the 329 DAG graphic pattern is shown in Figure 3.

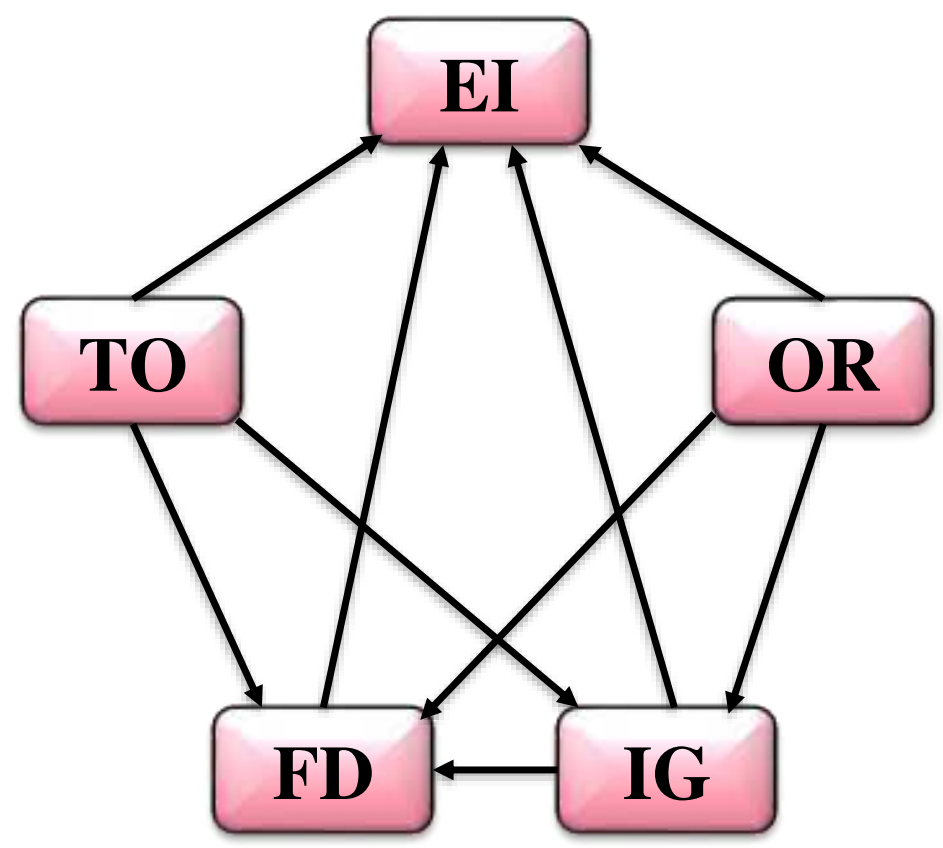

Figure 3 Directed Acyclic Graphs of LnFD, LnTO, LnIG, LnOR, and LnEI 
333 Then, according to the DAG results, we applied the zero restrictions to matrices B and $\Xi B$. As discussed above, 334 these restrictions are very robust and reliable, and are as follows:

$$
B=\left[\begin{array}{lllll}
* & * & * & * & * \\
* & * & * & * & * \\
* & * & * & * & * \\
* & * & * & * & * \\
* & * & * & * & *
\end{array}\right]
$$$$
\Xi B=\left[\begin{array}{lllll}
0 & * & * & * & * \\
0 & * & * & 0 & 0 \\
0 & 0 & * & 0 & 0 \\
0 & * & * & * & 0 \\
0 & * & * & * & *
\end{array}\right]
$$

336 In matrices, B and $\Xi B$, the columns represent the variables of oil revenues, financial development, energy intensity, 337 government investment, and trade openness, respectively. After applying these zero restrictions, the following 338 estimate was obtained by the maximum likelihood ratio method that the value in parentheses represents the t-statistic:

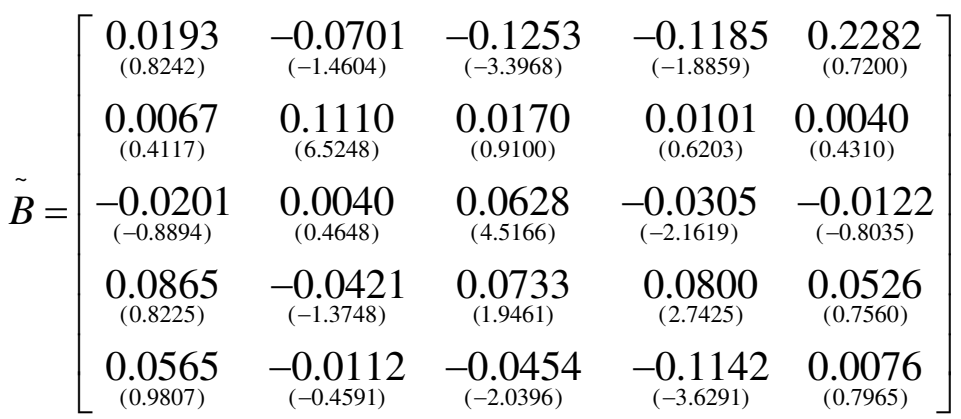

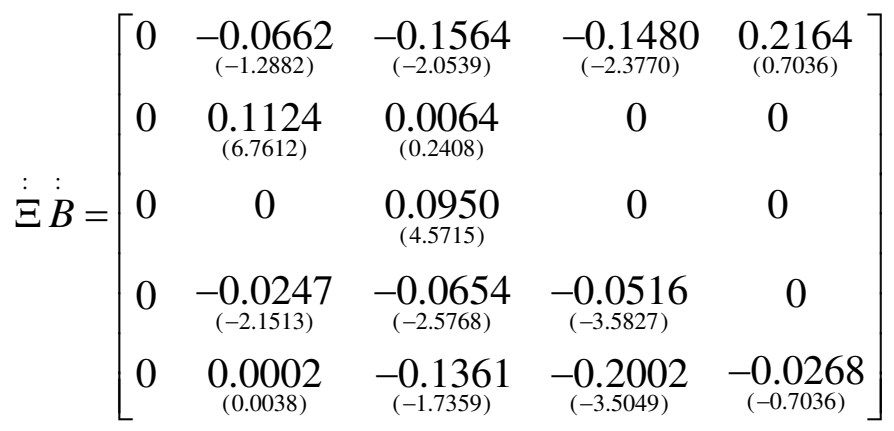

341 The estimation results show that the t-statistic of some matrix elements is small, and this may tempt us to identify more permanent and transitory effects. According to the results of unit root and cointegration tests, we were not 
343 allowed to impose further restrictions on the B and $\Xi B$ matrices. So, we conducted our analyzes based on the just-

344 identify model.

345 Now, according to structural innovation, we can analyze Impulse Response Functions (IRF). Figure 4 illustrates IRF

346 for 10 periods using the Cholesky Degree of Freedom. Due to the main focus of this study on energy intensity, here

347 we interpret the response of energy intensity to innovations of other variables in the confidence intervals of $90 \%$ and

$34895 \%$ determined by the Hall percentile method (See Appendix B). The results show that energy intensity responds

349 positively and insignificantly to financial development innovations during the 10 periods, which is more intense in the

350 initial periods and gradually decreases. Besides, energy intensity responds negatively to government investment, oil

351 revenues, and trade openness innovations and is also significant only in the early periods. The negative response of

352 the energy intensity to innovations of these variables indicates that if they increase one percent, the energy intensity

353 situation will worsen. 


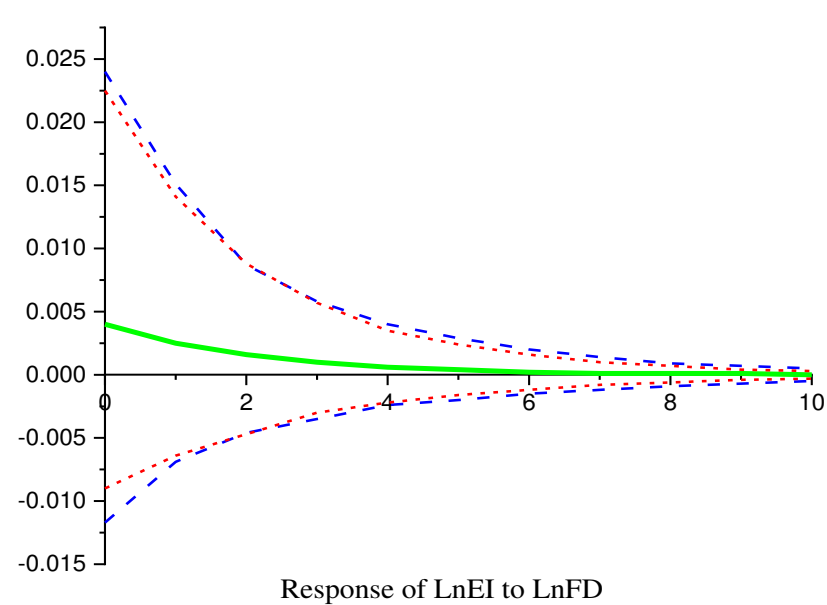

Response of LnEI to LnFD

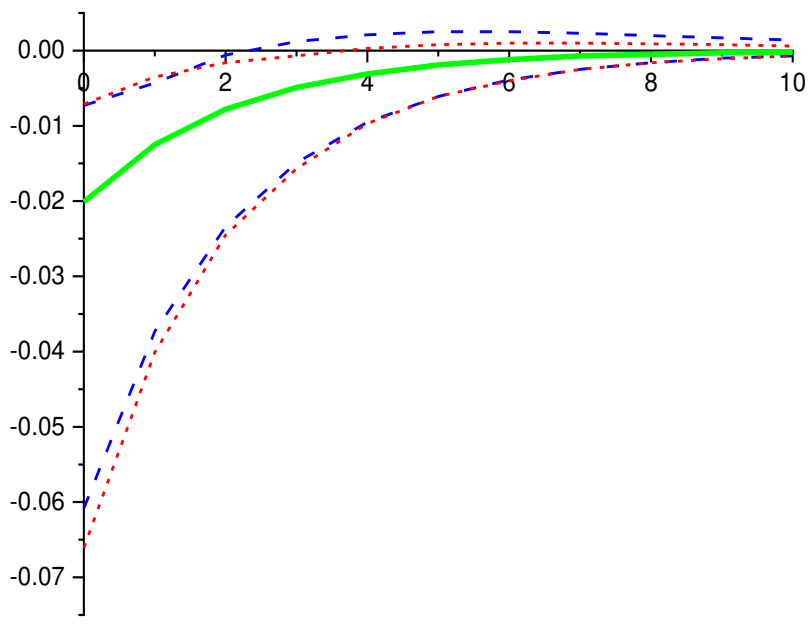

Respone of $\mathrm{LnEI}$ to $\mathrm{LnOR}$

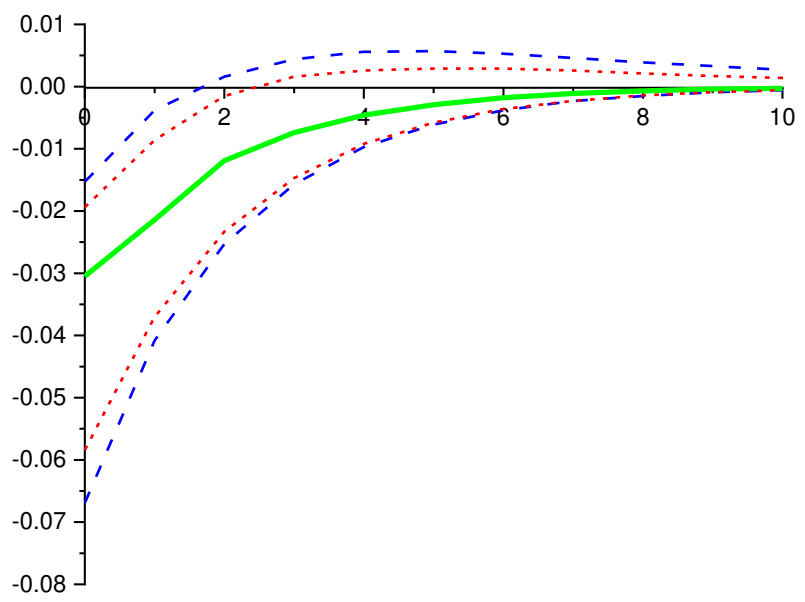

Response of LnEI to LnIG

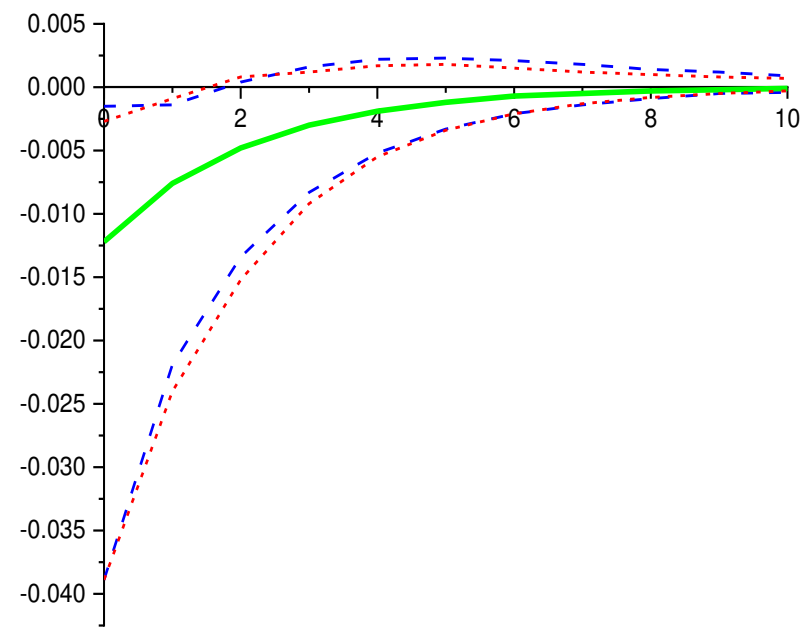

Response LnEI to LnTO

Figure 4 Structural Impulse Responses of LnEI to LnFD, LnIG, LnOR, and LnTO shocks

We analyze the variance decomposition, as the last step of the empirical analysis. Variance decomposition in the context of VEC and VAR models is interpreted as a part of the total variance of the variables derived from structural innovations (Taghizadeh-Hesary et al., 2020). Variance decomposition shows the explanatory power of variables for energy intensity variations (see Appendix C ). Figure 5 shows the results of variance decomposition, which is restricted to 10 periods. The results show that the strongest variation in energy intensity is explained by its innovations and increases in the long-run. Also, government investment, oil revenues, and trade openness in the early periods have a greater impact on energy intensity variations and their effects are gradually diminishing. It is worth noting that the 

nor in the long-run.
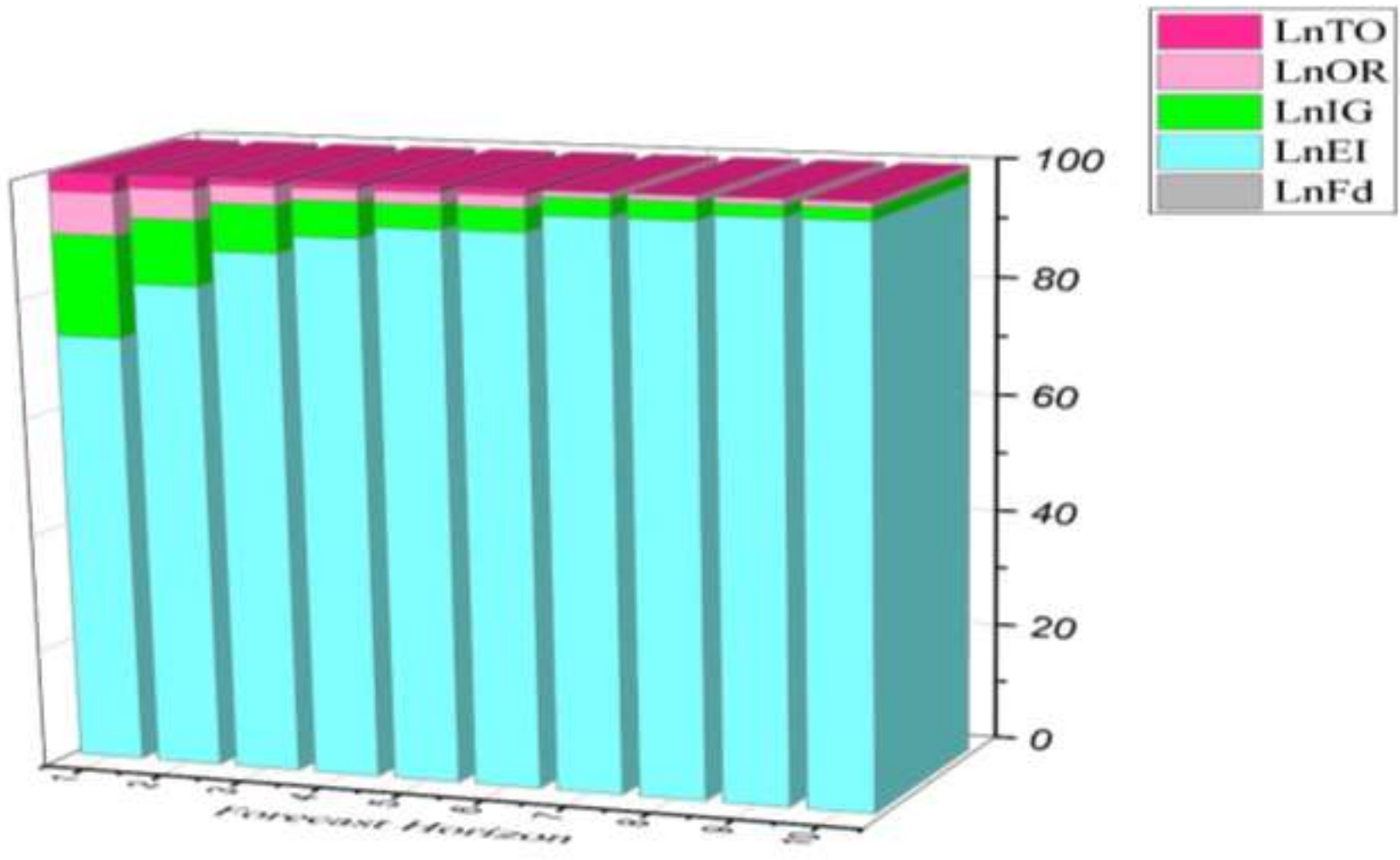

Figure 5 Variance decomposition of energy intensity

\section{Conclusion and Policy implications}

371 One of the strategic policies pursued by most countries is to improve energy efficiency by reducing energy intensity.

372 The fundamental question is which policies must be adopted to be effective. Given the focus of this study on Iran's

373 energy intensity, we examined the impact of financial development, government investment, oil revenues, and trade

374 openness on energy intensity. To this end, we used SVECM and DAG technique and considered the data from 1967

375 to 2017. Empirical results shed light on that government investment, oil revenues, and trade openness influence energy

376 intensity negatively and also the impact of financial development on the intensity of energy is positive. Likewise, 
377 government investment and financial development have the main and minor effects on variations of energy intensity, 378 respectively.

379 Among the conventional econometric models, VEC and VAR models are so common to inspect the relationship 380 between variables. Implementing VEC and VAR models is a simple task and researchers do not require to identify 381 endogenous and exogenous variables. In contrast, VEC and VAR models, unlike simultaneous equations, are not 382 based on economic theories. Thus, the interpretation of these models coefficients is naive and they can analyze the 383 behaviors of the variables based on methods such as impulse response functions. It is worth noting that, forecasting 384 made by VEC and VAR models is usually better than the simultaneous equation's forecasting.

Albeit the limitations of VEC and VAR models, we used the SVECM through which we can include the structure of the Iranian economy in model estimation. Furthermore, we combined the results of the SVECM with data science in the form of the DAG technique. The latter technique, in addition to data, the results of previous studies can be considered in the knowledge box. Thus, the structure of the economy, the data, and the results of previous studies are taken into account in estimating the model.

Our upshots have particular importance to policymakers because if it does not pay attention to the state of energy intensity, Iran will become one of the energy importers in the coming years. Accordingly, we suggest that the government increase its investment to optimize energy consumption. It is impossible to ignore the role of oil revenues in OPEC member countries. Therefore, it is recommended to improve energy intensity by using oil revenues in constructive projects and also improve the level of trade openness. Usually, the private sector doesn't seek to save energy. Hence, we proposed that the government forces the private sector by imposing regulations and taxes to reduce energy losses.

397 In line with studies on energy intensity, our results confirm the studies such as Aboagye (2017), Adom (2018); and

398 Samargandi (2019) on the inverse effect of trade openness on energy intensity. Also, our results are not similar to 399 Chen et al. (2019) and Pan, Uddin, Han, et al. (2019), because they believe the impact of financial developments on 400 the intensity of energy is negative. The result of He and Huang (2019) is the negative impact of investment on energy 401 intensity, as we have seen, the effect of government investment on energy intensity is negative in Iran. Regarding oil 402 revenues, we did not find a study that examined the relationship between oil revenues and energy intensity, and 

variable in studies in this field.

To get more accurate results, according to the economies of countries, more and newer variables such as exchange

406 rate and economic policies can be added to the model. On the other hand, instead of considering the energy intensity

407 in general, the energy intensity of energy carriers can be examined separately, similar to Guo et al. (2019) and

408 McKenzie et al. (2019) studies. Also, instead of using SVECM, models such as general equilibrium can be used to 409 examine the relationship between variables like He and Huang (2020).

\section{Declaration of interest}

411 The authors declare that they have no known competing financial interests or personal relationships that could have

412 appeared to influence the work reported in this paper.

\section{Acknowledgment}

414 We would like to express our sincere thanks to the editor and reviewers of the Environmental Science and Pollution 415 Research Journal for their very helpful suggestions and constructive comments with significantly improved the quality 416 of the manuscript.

417 Consent to Publish not applicable

418 Consent to Participate not applicable

419 Author Contributions

420 -Parisa Esmaeili: Writing-original draft, Writing-review \& editing, Formal analysis, Investigation, Software, 421 Methodology, Data curation

422 -Meysam Rafei: Conceptualization, Writing-original draft, Writing-review \& editing, Supervision, Formal analysis, 423 Methodology, Data curation, Software, Validation

424 Availability of data and materials All data and materials used in the current study are available publicly. 


\section{5 \\ Compliance with Ethical Standards}

426

427

428

429

430

431

432

433

Funding This research received no specific grant from any funding agency in the public, commercial, or not-for-profit sectors.

Ethical approval This article does not contain any studies with human participants or animals performed by any of the authors.

Conflict of interest The authors declare that there is no conflict of interests regarding the publication of this paper.

\section{References}

Aboagye, S. (2017). The policy implications of the relationship between energy consumption, energy intensity and economic growth in Ghana. OPEC Energy Review, 41(4), 344-363.

Acheampong, A. O. (2019). Modelling for insight: Does financial development improve environmental quality? Energy Economics, 83, 156-179.

Adom, P. K. (2015). Asymmetric impacts of the determinants of energy intensity in Nigeria. Energy Economics, 49, 570-580.

Adom, P. K. (2018). The Long-run Effects of Political Regimes and Economic Openness on Energy Intensity. African Development Review, 30(4), 399-409.

Adom, P. K. (2019). Energy indices: A risk factor or not in the financial sector. Energy Strategy Reviews, 24, 14-26.

Aller, C., Herrerias, M. J., \& Ordóñez, J. (2018). The effect of financial development on energy intensity in China. The Energy Journal, 39(Special Issue 1).

Balance, I. s. E. (2017). Iran's Energy Balance.

balance", I. s. e. (2017).

Barkhordari, S., \& Fattahi, M. (2017). Reform of energy prices, energy intensity and technology: A case study of Iran (ARDL approach). Energy strategy reviews, 18, 18-23.

Benjamin, N. I., \& Lin, B. (2020). Quantile analysis of carbon emissions in China metallurgy industry. Journal of Cleaner Production, 243, 118534.

Bessler, D. A., \& Yang, J. (2003). The structure of interdependence in international stock markets. Journal of international money and finance, 22(2), 261-287.

Bi, C., Jia, M., \& Zeng, J. (2019). Nonlinear effect of public infrastructure on energy intensity in China: A panel smooth transition regression approach. Sustainability, 11(3), 629.

Bonga-Bonga, L., \& Kabundi, A. (2015). Monetary policy instrument and inflation in South Africa: Structural vector error correction model approach.

Boufateh, T., Ajmi, A. N., El Montasser, G., \& Issaoui, F. (2013). Dynamic relationship between energy consumption and income in Tunisia: A SVECM approach. 
Breisinger, C., Diao, X., Schweickert, R., \& Wiebelt, M. (2010). Managing future oil revenues in Ghana: An assessment of alternative allocation options. African Development Review, 22(2), 303-315.

Breitung, J., Brüggemann, R., \& Lütkepohl, H. (2004). Structural vector autoregressive modeling and impulse responses. Applied time series econometrics.

Cao, W., Chen, S., \& Huang, Z. (2020). Does Foreign Direct Investment Impact Energy Intensity? Evidence from Developing Countries. Mathematical Problems in Engineering, 2020.

Chen, Z., Huang, W., \& Zheng, X. (2019). The decline in energy intensity: Does financial development matter? Energy Policy, 134, 110945.

Deichmann, U., Reuter, A., Vollmer, S., \& Zhang, F. (2019). The relationship between energy intensity and economic growth: New evidence from a multi-country multi-sectorial dataset. World Development, 124, 104664.

Demiralp, S., \& Hoover, K. D. (2003). Searching for the causal structure of a vector autoregression. Oxford Bulletin of Economics and statistics, 65, 745-767.

Dickey, D. A., \& Fuller, W. A. (1979). Distribution of the estimators for autoregressive time series with a unit root. Journal of the American statistical association, 74(366a), 427-431.

Du, D., \& Lei, H. (2017). Energy intensity and its determinants in China: an empirical study based on ARDLVECM approach. Chinese Journal of Population Resources and Environment, 15(3), 226-238.

Erdogan, S. (2020). Analyzing the environmental Kuznets curve hypothesis: The role of disaggregated transport infrastructure investments. Sustainable Cities and Society, 102338.

Fu, F., Liu, H., Polenske, K. R., \& Li, Z. (2013). Measuring the energy consumption of China's domestic investment from 1992 to 2007. Applied energy, 102, 1267-1274.

GFDD. (2019). Global Financial Development.

Gómez, M., \& Rodríguez, J. C. (2019). Energy consumption and financial development in NAFTA countries, 1971-2015. Applied Sciences, 9(2), 302.

Granger, C. W. (1969). Investigating causal relations by econometric models and cross-spectral methods. Econometrica: journal of the Econometric Society, 424-438.

Guo, Z., Zhang, X., Ding, Y., \& Zhao, X. (2019). A Forecasting Analysis on China 'S Energy Use and Carbon Emissions Based on A Dynamic Computable General Equilibrium Model. Emerging Markets Finance and Trade, 1-13.

Hasanov, F. J. (2020). Electricity incentives for agriculture in Saudi Arabia. Is that relevant to remove them? Energy Policy, 144, 111589.

He, Y., \& Huang, H. (2019). Energy intensity in Guangdong of China (2006-2015): A spatial dynamic general equilibrium econometric model. Natural Resource Modeling, e12247.

He, Y., \& Huang, H. (2020). Energy intensity in Guangdong of China (2006-2015): A spatial dynamic general equilibrium econometric model. Natural Resource Modeling, 33(1), e12247.

Hossain, M. S., \& Mitra, R. (2013). The determinants of economic growth in Africa: a dynamic causality and panel cointegration analysis. Economic analysis and policy, 43(2), 217.

Hosseini Nasab, E., Aalami, R., Foroughi Dahr, S., \& Sadeghzadeh, M. A. (2012). An analysis of energy consumption in transportation and industrial sectors-a multiplicative LMDI approach with application to Iran. Iranian Economic Review, 16(32), 1-17.

Ivrendi, M., \& Guloglu, B. (2010). Monetary shocks, exchange rates and trade balances: Evidence from inflation targeting countries. Economic Modelling, 27(5), 1144-1155.

Ji, Q., Zhang, H.-Y., \& Geng, J.-B. (2018). What drives natural gas prices in the United States?-A directed acyclic graph approach. Energy Economics, 69, 79-88.

Johansen, S. (1995). Likelihood-based inference in cointegrated vector autoregressive models: Oxford University Press on Demand. 
Johansen, S., \& Juselius, K. (1990). Maximum likelihood estimation and inference on cointegration -with applications to the demand for money. Oxford Bulletin of Economics and statistics, 52(2), 169210.

Kahouli, B. (2017). The short and long run causality relationship among economic growth, energy consumption and financial development: Evidence from South Mediterranean Countries (SMCs). Energy Economics, 68, 19-30.

Karanfil, F. (2009). How many times again will we examine the energy-income nexus using a limited range of traditional econometric tools? Energy Policy, 37(4), 1191-1194.

Khan, Z., Hussain, M., Shahbaz, M., Yang, S., \& Jiao, Z. (2020). Natural resource abundance, technological innovation, and human capital nexus with financial development: a case study of China. Resources Policy, 65, 101585.

King, R., Plosser, C., Stock, J., \& Watson, M. (1991). Stochastic Trends and Economic Fluctuations. American Economic Review, 81(4), 819-840.

Lütkepohl, H. (2005). New introduction to multiple time series analysis: Springer Science \& Business Media.

MacKinnon, J. G. (1996). Numerical distribution functions for unit root and cointegration tests. Journal of applied econometrics, 11(6), 601-618.

McKenzie, L. M., Crooks, J., Peel, J. L., Blair, B. D., Brindley, S., Allshouse, W. B., . . Adgate, J. L. (2019). Relationships between indicators of cardiovascular disease and intensity of oil and natural gas activity in Northeastern Colorado. Environmental research, 170, 56-64.

Miljkovic, D., Dalbec, N., \& Zhang, L. (2016). Estimating dynamics of US demand for major fossil fuels. Energy Economics, 55, 284-291.

Mirzaei, M., \& Bekri, M. (2017). Energy consumption and CO2 emissions in Iran, 2025. Environmental research, 154, 345-351.

Nizamani, A. R., Karim, Z. A., Zaidi, M. A. S., \& Khalid, N. (2017). TRADE BALANCE RESPONSE TO SHOCKS IN MONETARY POLICY AND EXCHANGE RATE: EVIDENCE FROM PAKISTAN USING SVECM APPROACH. International Journal of Business \& Society, 18(3).

OPEC. (2020). Organization of the Petroleum Exporting Countries.

Pan, X., Ai, B., Li, C., Pan, X., \& Yan, Y. (2019). Dynamic relationship among environmental regulation, technological innovation and energy efficiency based on large scale provincial panel data in China. Technological Forecasting and Social Change, 144, 428-435.

Pan, X., Uddin, M. K., Han, C., \& Pan, X. (2019). Dynamics of financial development, trade openness, technological innovation and energy intensity: Evidence from Bangladesh. Energy, 171, 456-464.

Pan, X., Uddin, M. K., Saima, U., Guo, S., \& Guo, R. (2019). Regime switching effect of financial development on energy intensity: Evidence from Markov-switching vector error correction model. Energy Policy, 135, 110995.

Pasierb, S., Niedziela, K., \& Wojtulewicz, J. (1996). Structural and technological changes of greenhouse gas emissions during the transition period in Polish industry. Environmental Management, 20(1), S37S45.

Pearl, J. (2000). Models, reasoning and inference. Cambridge, UK: CambridgeUniversityPress.

Pham, N. M., Huynh, T. L. D., \& Nasir, M. A. (2020). Environmental consequences of population, affluence and technological progress for European countries: A Malthusian view. Journal of Environmental Management, 260, 110143.

Phillips, P. C., \& Perron, P. (1988). Testing for a unit root in time series regression. Biometrika, 75(2), 335346.

Rodríguez, J. D. G. (2020). Oil revenues, public procurement and armed conflict: A case study of a subnational government in Colombia. The Extractive Industries and Society.

Sadorsky, P. (2010). The impact of financial development on energy consumption in emerging economies. Energy Policy, 38(5), 2528-2535. 
Sadorsky, P. (2013). Do urbanization and industrialization affect energy intensity in developing countries? Energy Economics, 37, 52-59.

Samargandi, N. (2019). Energy intensity and its determinants in OPEC countries. Energy, 186, 115803.

Shahbaz, M., \& Lean, H. H. (2012). Does financial development increase energy consumption? The role of industrialization and urbanization in Tunisia. Energy Policy, 40, 473-479.

Sims, C. A. (1980). Macroeconomics and reality. Econometrica: journal of the Econometric Society, 1-48.

Spirtes, P., Glymour, C. N., Scheines, R., \& Heckerman, D. (2000). Causation, prediction, and search: MIT press.

Sun, J. (1998). Changes in energy consumption and energy intensity: a complete decomposition model. Energy Economics, 20(1), 85-100.

Taghizadeh-Hesary, F., Mortha, A., Farabi-Asl, H., Sarker, T., Chapman, A., Shigetomi, Y., \& Fraser, T. (2020). Role of energy finance in geothermal power development in Japan. International Review of Economics \& Finance.

Tamazian, A., Chousa, J. P., \& Vadlamannati, K. C. (2009). Does higher economic and financial development lead to environmental degradation: evidence from BRIC countries. Energy Policy, 37(1), 246-253.

Wang, Y., \& Gong, X. (2020). Does financial development have a non-linear impact on energy consumption? Evidence from 30 provinces in China. Energy Economics, 104845.

Wang, Y., Lei, X., Long, R., \& Zhao, J. (2020). Green Credit, Financial Constraint, and Capital Investment: Evidence from China's Energy-intensive Enterprises. Environmental Management, 66(6), 10591071.

Wang, Z., Yang, J., \& Li, Q. (2007). Interest rate linkages in the Eurocurrency market: Contemporaneous and out-of-sample Granger causality tests. Journal of international money and finance, 26(1), 86103.

WDI. (2019). World Bank Indicator.

Yang, J., \& Bessler, D. A. (2008). Contagion around the October 1987 stock market crash. European Journal of Operational Research, 184(1), 291-310.

Yang, J., Guo, H., \& Wang, Z. (2006). International transmission of inflation among G-7 countries: A datadetermined VAR analysis. Journal of Banking \& Finance, 30(10), 2681-2700.

Yıldırım, S., Gedikli, A., Erdoğan, S., \& Yıldırım, D. Ç. (2020). Natural resources rents-financial development nexus: Evidence from sixteen developing countries. Resources Policy, 68, 101705.

Zaidi, S. A. H., Zafar, M. W., Shahbaz, M., \& Hou, F. (2019). Dynamic linkages between globalization, financial development and carbon emissions: Evidence from Asia Pacific Economic Cooperation countries. Journal of Cleaner Production, 228, 533-543.

Zhu, J., \& Lin, B. (2020). Convergence analysis of city-level energy intensity in China. Energy Policy, 139, 111357.

\section{Appendix A}

The VECM is constructed by differentiating from the variables and long-run error terms. Also, the number of lags in VECM is one less than the VAR model. Since the number of optimal lags in 
593 the VAR model was one, the number of lags in the current pattern is zero. Hence, the desired

594 VECM is as follows:

595

$$
\left[\begin{array}{c}
\Delta(\text { LnOR })_{t} \\
\Delta(\text { LnFD })_{t} \\
\Delta(\text { LnEI })_{t} \\
\Delta(\text { LnIG })_{t} \\
\Delta(\text { LnTO })_{t}
\end{array}\right]=\left[\begin{array}{l}
\alpha_{1} \\
\alpha_{2} \\
\alpha_{3} \\
\alpha_{4} \\
\alpha_{5}
\end{array}\right]\left[\begin{array}{lllll}
\beta_{1} & \beta_{2} & \beta_{3} & \beta_{4} & \beta_{5}
\end{array}\right]\left[\begin{array}{l}
(L n O R)_{t-1} \\
(L n F D)_{t-1} \\
(L n E I)_{t-1} \\
(L n I G)_{t-1} \\
(L n T O)_{t-1}
\end{array}\right]+\left[\begin{array}{l}
u_{1 t} \\
u_{2 t} \\
u_{3 t} \\
u_{4 t} \\
u_{5 t}
\end{array}\right]
$$

596 We fitted our VECM with a constant and one cointegrating rank. The following results were 597 obtained after estimating the VECM:

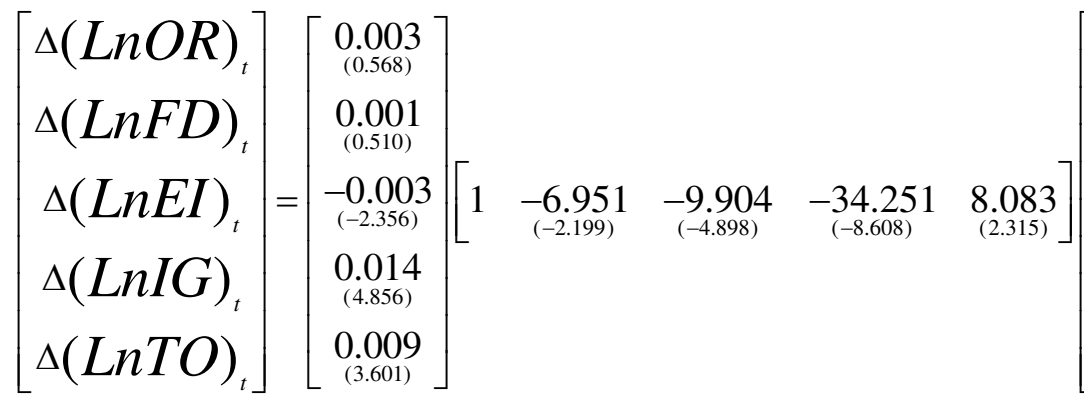

$$
\left[\begin{array}{l}
(\text { LnOR })_{t-1} \\
(\text { LnFD })_{t-1} \\
(\text { LnEI })_{t-1} \\
(L n I G)_{t-1} \\
(L n T O)_{t-1}
\end{array}\right]+\left[\begin{array}{c}
0.144 \\
(0.507) \\
0.083 \\
(0.762) \\
-0.130 \\
(-1.828) \\
0.699 \\
(4.717) \\
0.470 \\
(3.604)
\end{array}\right]+\left[\begin{array}{l}
u_{1 t} \\
u_{2 t} \\
u_{3 t} \\
u_{4 t} \\
u_{5 t}
\end{array}\right]
$$

599 As previously noted, there is a long-run relationship between variables. It is now clear from the t600 statistic shown in parentheses that these coefficients are significant.

601 Appendix B

602 Here the IRF of financial development, government investment, and trade openness are displayed.

603 Figure.B. 1, Figure.B. 2, Figure.B. 3 illustrates the Structural IRF of financial development, 604 government investment, and trade openness to other variables, respectively. The oil revenues are 605 not dependent on Iran's macroeconomic variables, so we did not examine it. 


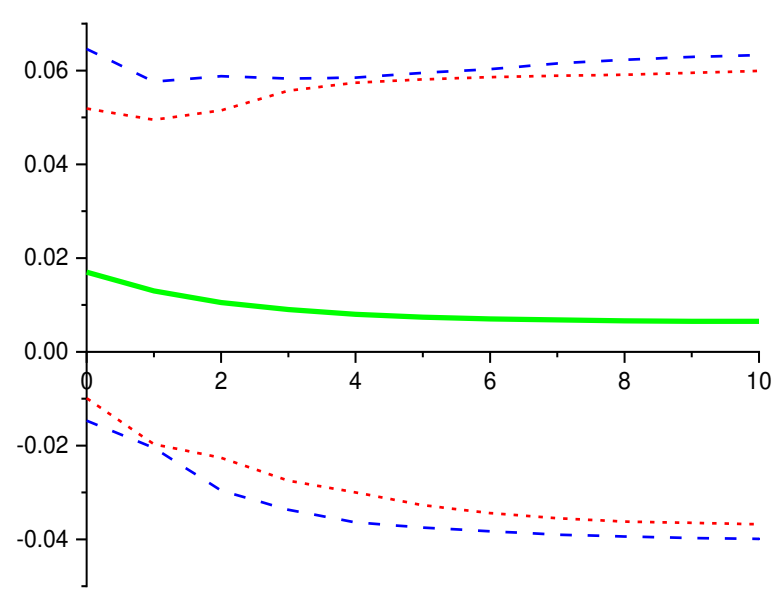

Response LnFD to LnEI

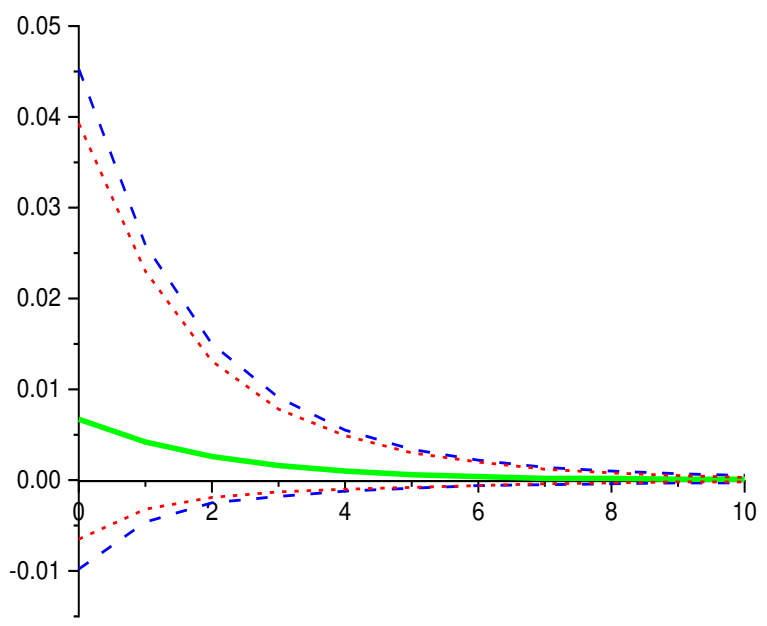

Response of LnFD to LnOR

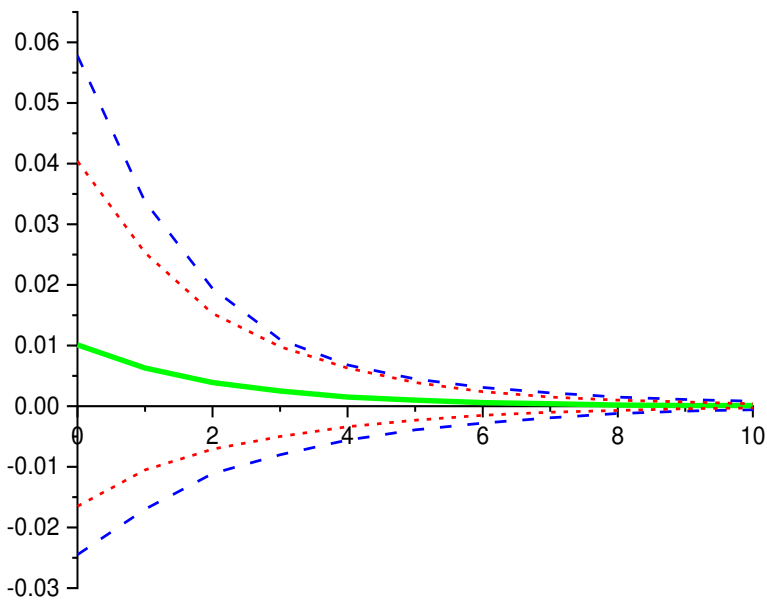

Response of LnFD to LnIG

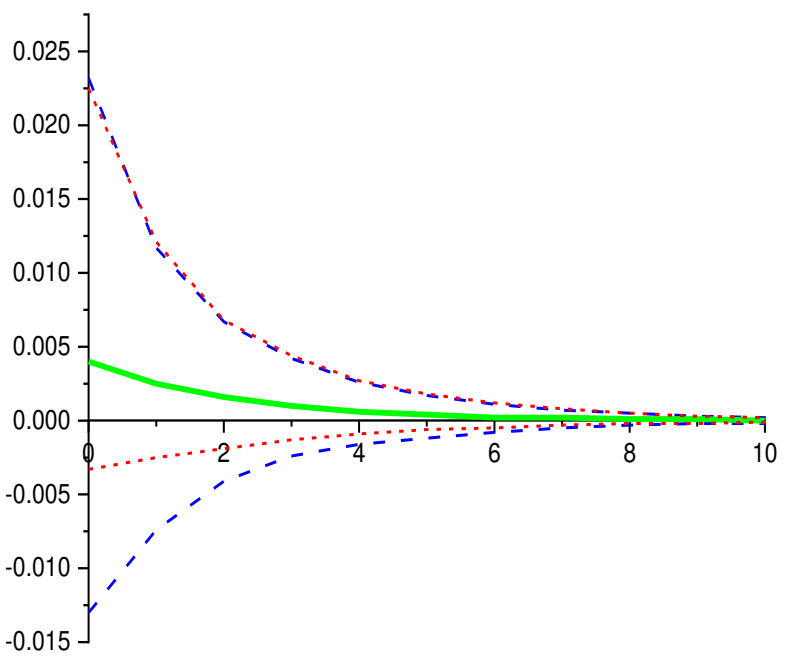

Response LnFd to LnTO

606

Figure.B. 1 Structural Impulse Responses of LnFD to LnEI, LnIG, LnOR, and LnTO shocks 


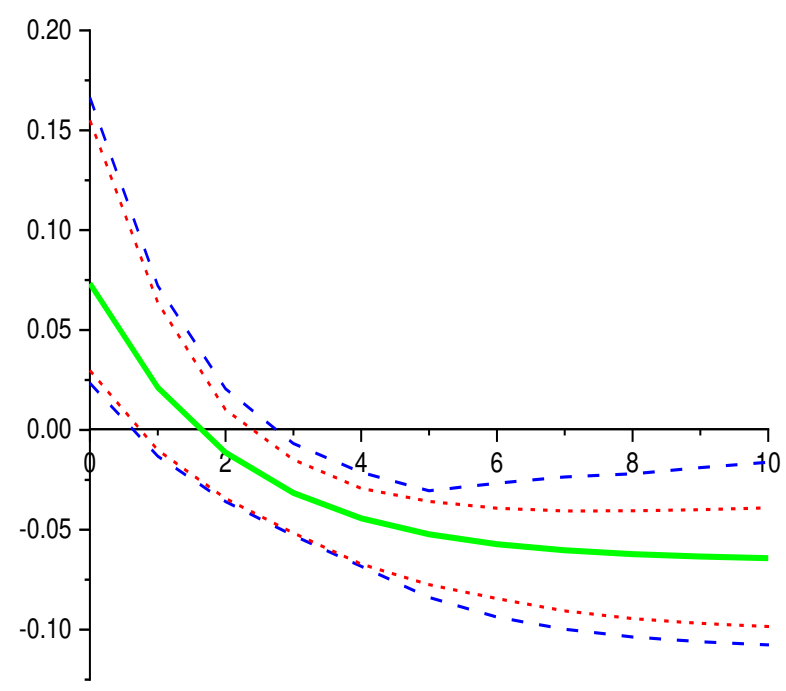

Response LnIG to LnEI

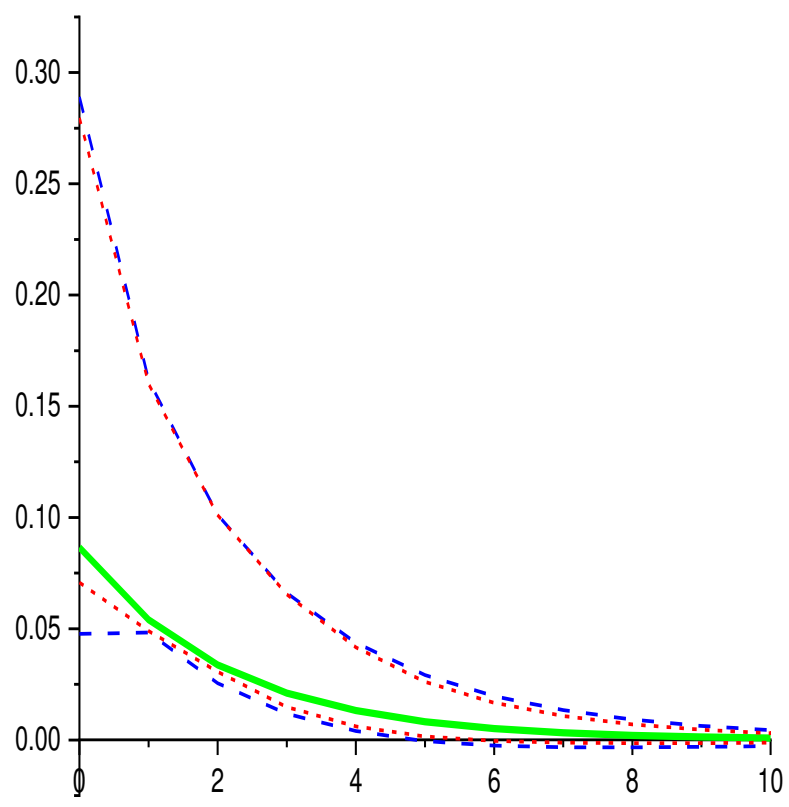

Response of LnIG to LnOR

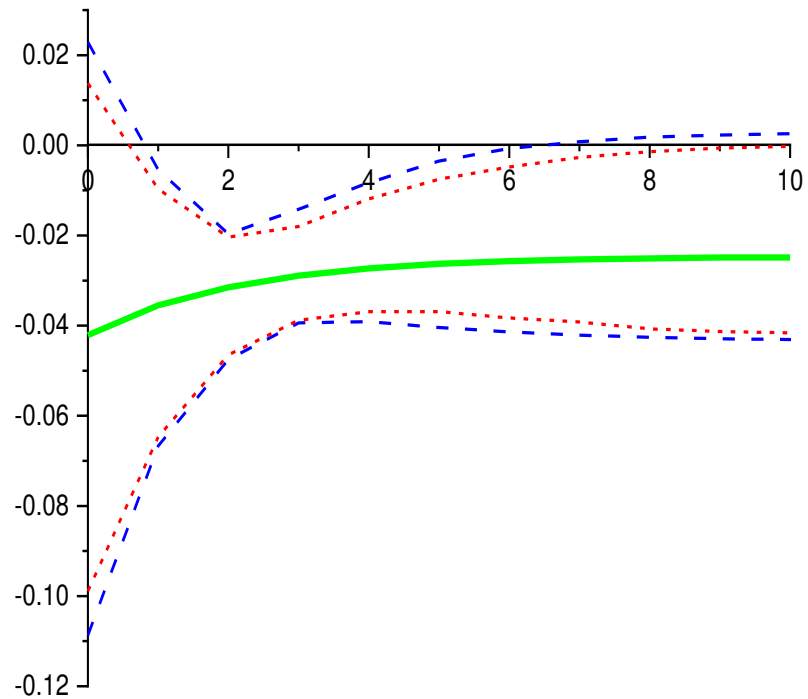

Response LnIG to LnFD

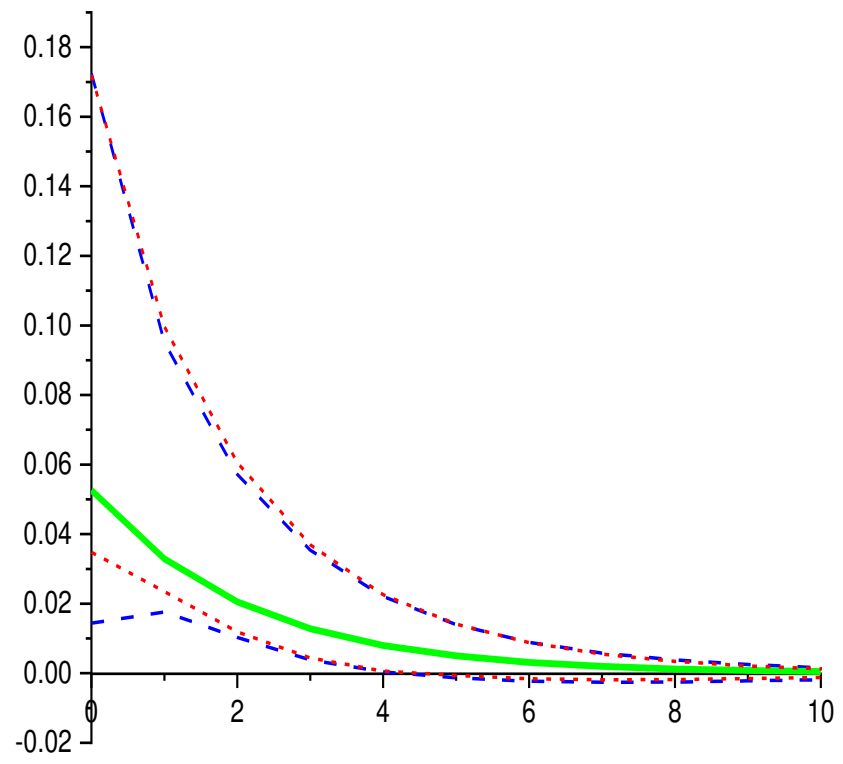

Response of LnIG to LnTO

Figure.B. 2 Structural Impulse Responses of LnIG to LnEI, LnFD, LnOR, and LnTO shocks 


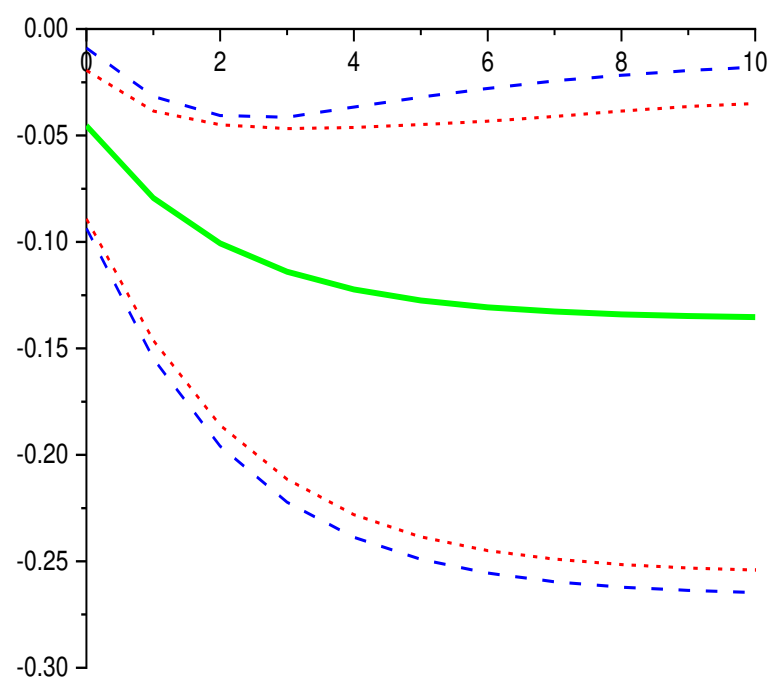

Response Of LnTO to LnEI

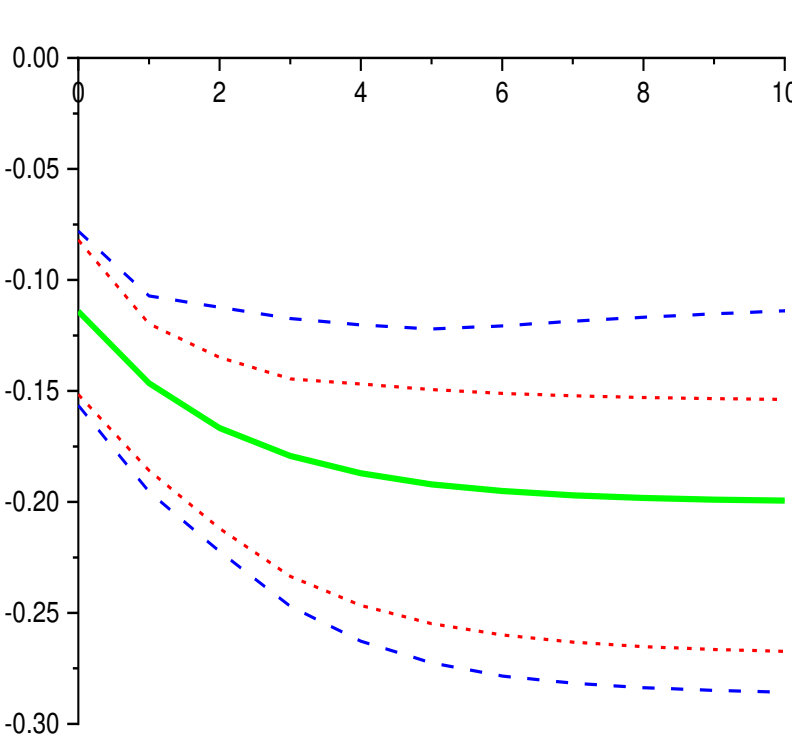

Response of LnTO to LnIG

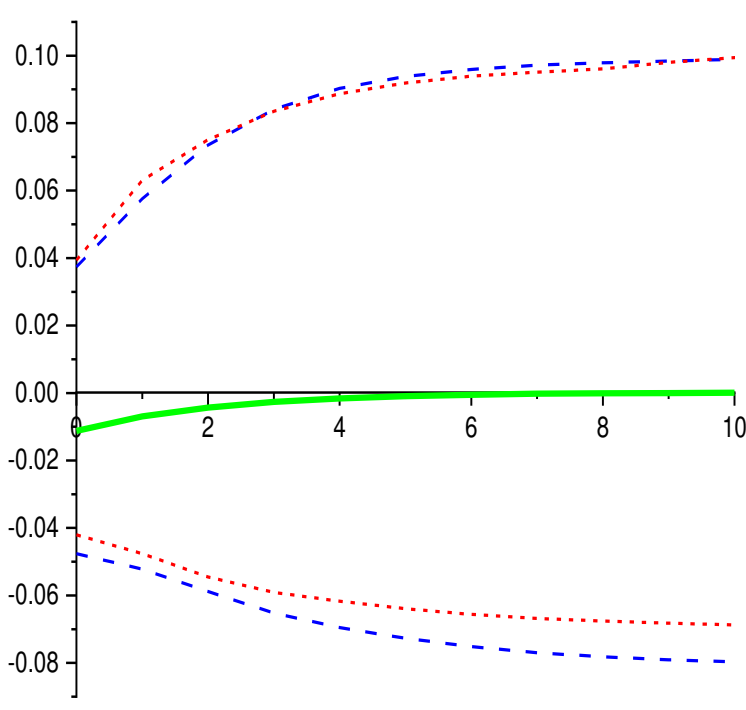

Response of LnTo to LnFD

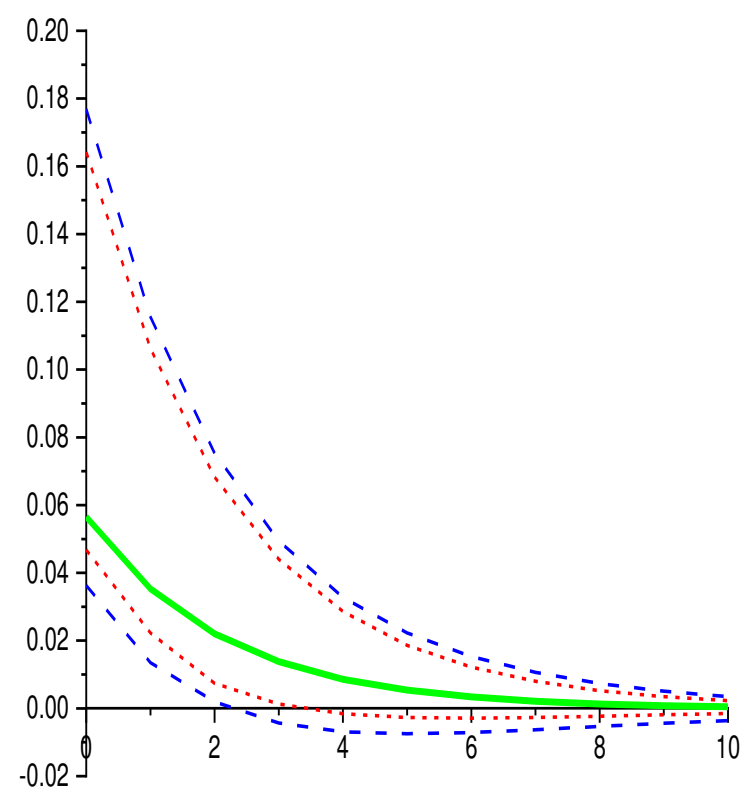

Response LnTO to LnOR

611 


\section{Appendix C}

616 We have already discussed the variance decomposition of energy intensity and here we are going

617 to analyze the variance decomposition of other variables. Figure.C. 1, Figure.C. 2, Figure.C. 3

618 represents the variance decomposition of financial development, government investment, and

619 trade openness, respectively. Oil revenues are an exogenous variable, so we did not examine it.
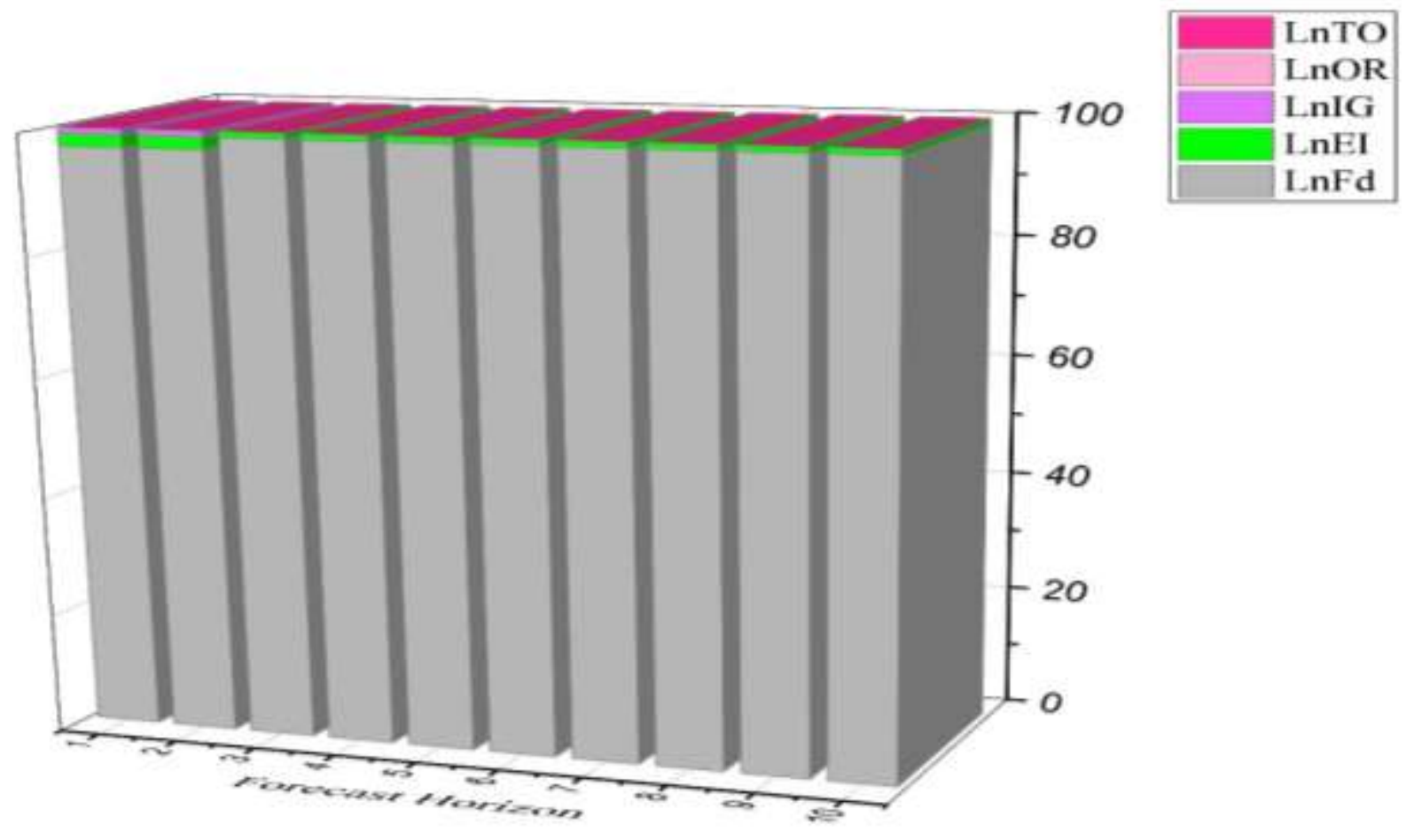

620

621

Figure.C. 1 Variance decomposition of Financial development

622

623 


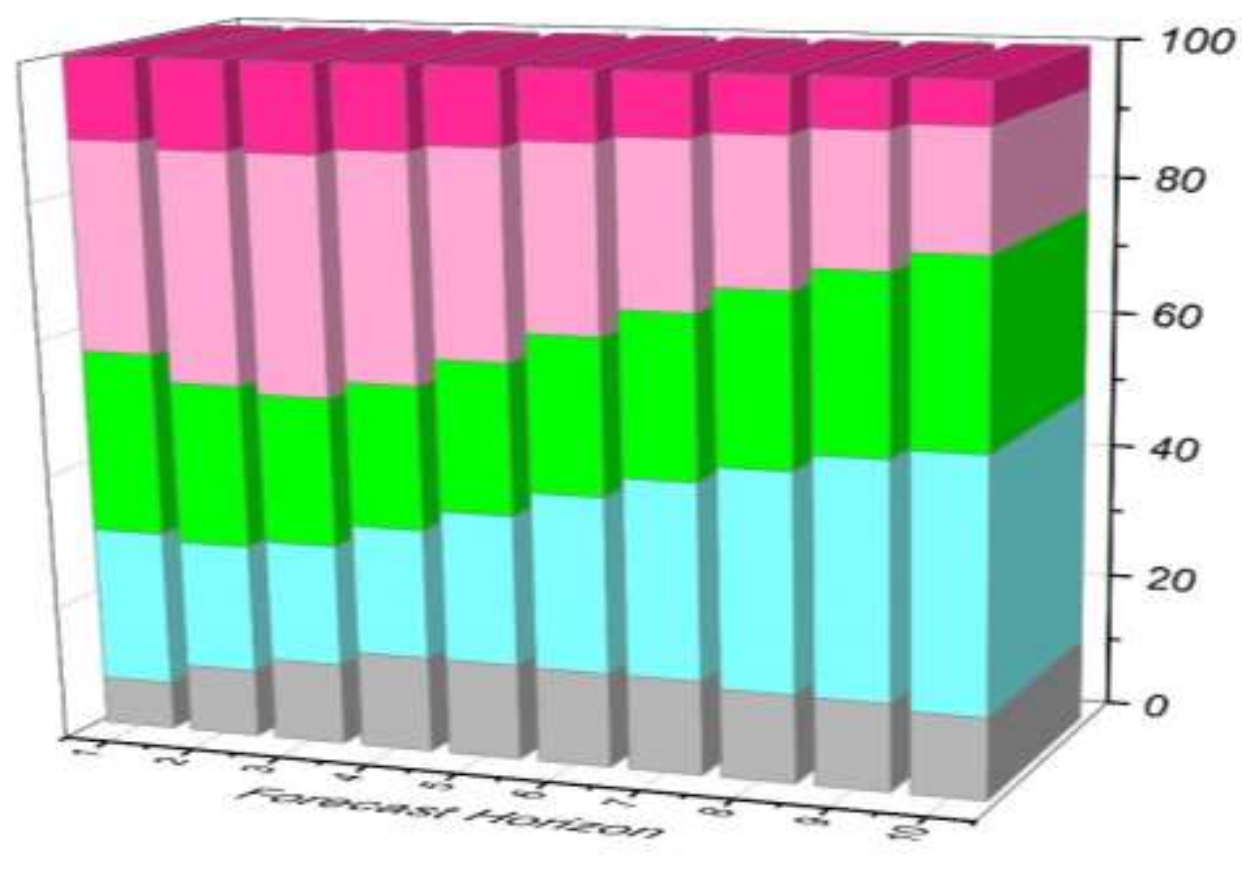

\begin{tabular}{|l|l|}
\hline LnTO \\
\hline LnOR \\
\hline LnIG \\
\hline LnEI \\
\hline LnFd \\
\hline
\end{tabular}

624

625

Figure.C. 2 Variance decomposition of Government investment

626

627

628 


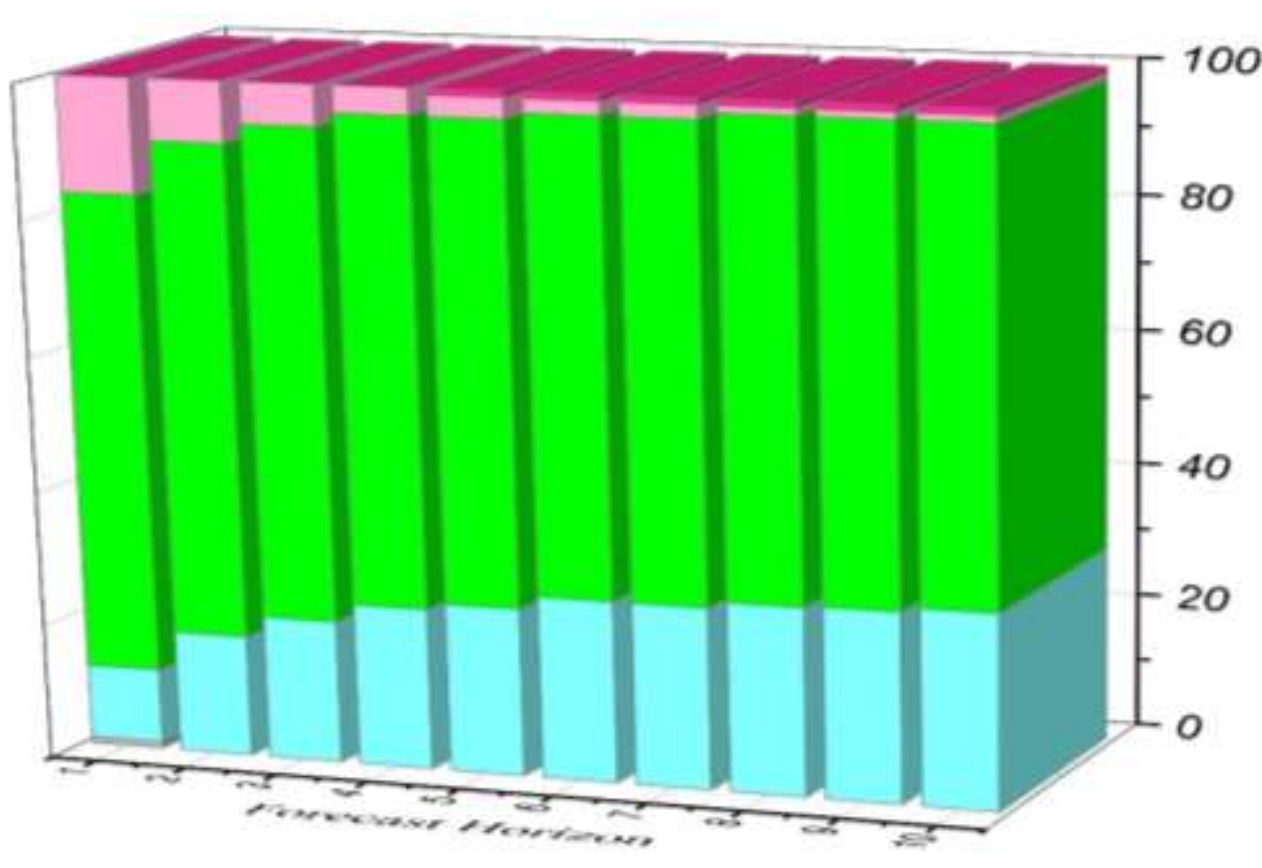

\begin{tabular}{|l|l|}
\hline LnTO \\
\hline LnOR \\
\hline LnIG \\
\hline LnEI \\
LnFd \\
\hline
\end{tabular}

629

630

Figure.C. 3 Variance decomposition of trade openness

631

632 


\section{Figures}

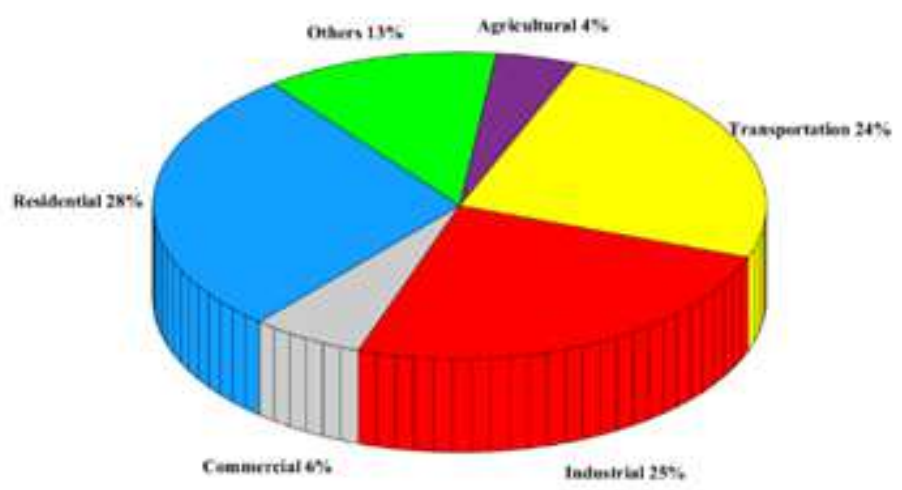

Figure 1

Contribution of different energy-consuming sectors in Iran Source: Iran's energy balance (2017)

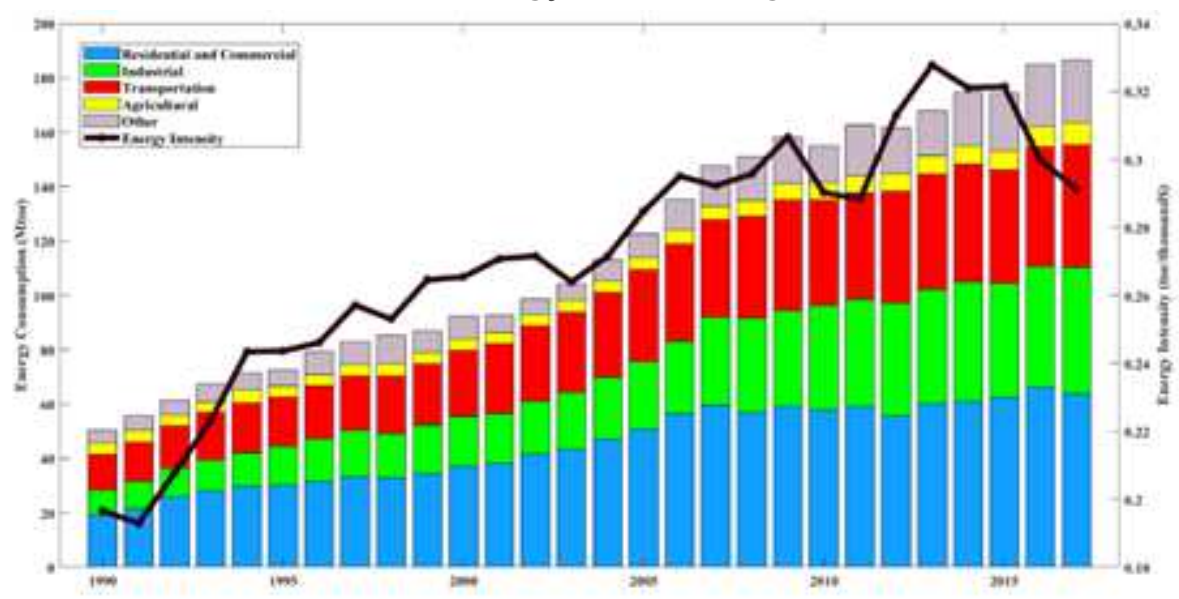

Figure 2

Energy consumption vs energy intensity Source: Iran's energy balance (2017) 


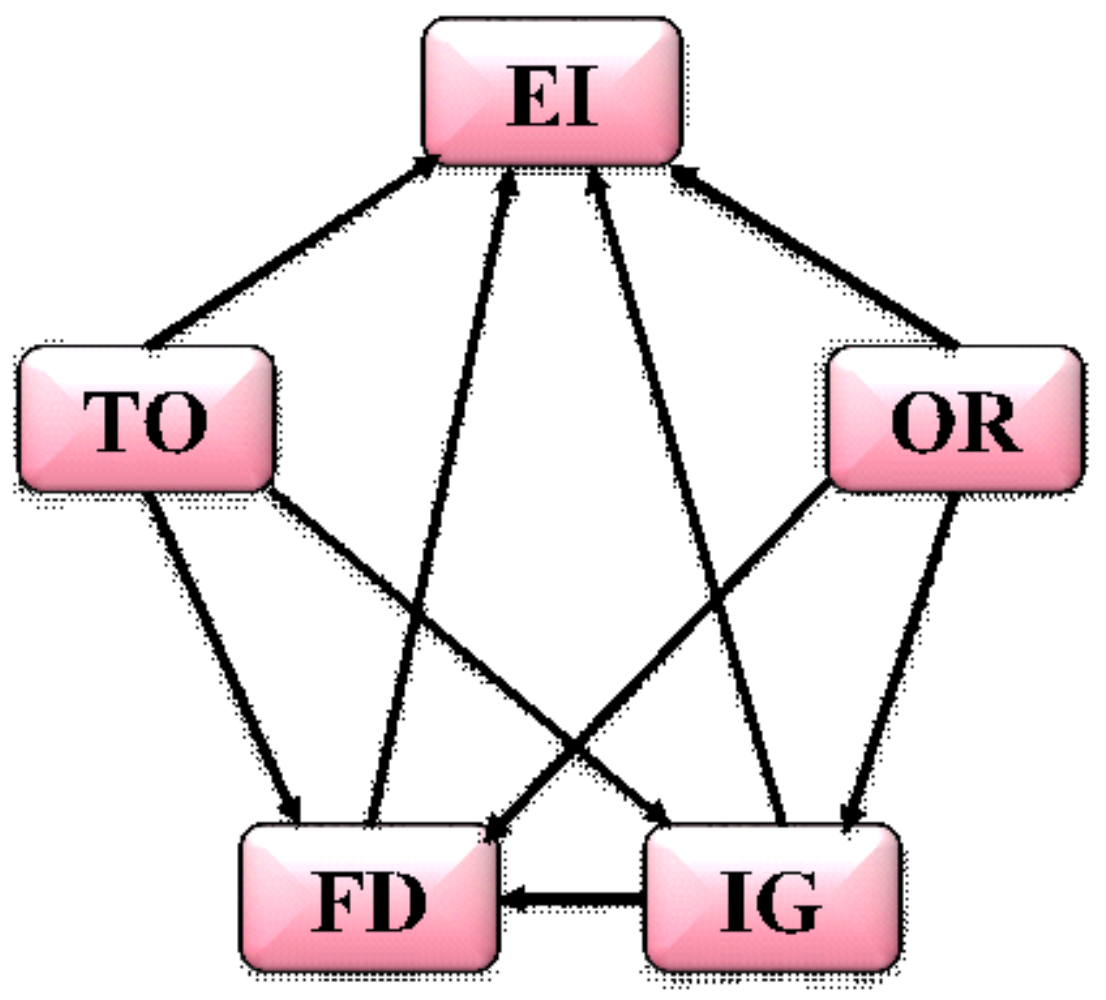

Figure 3

Directed Acyclic Graphs of LnFD, LnTO, LnIG, LnOR, and LnEI 

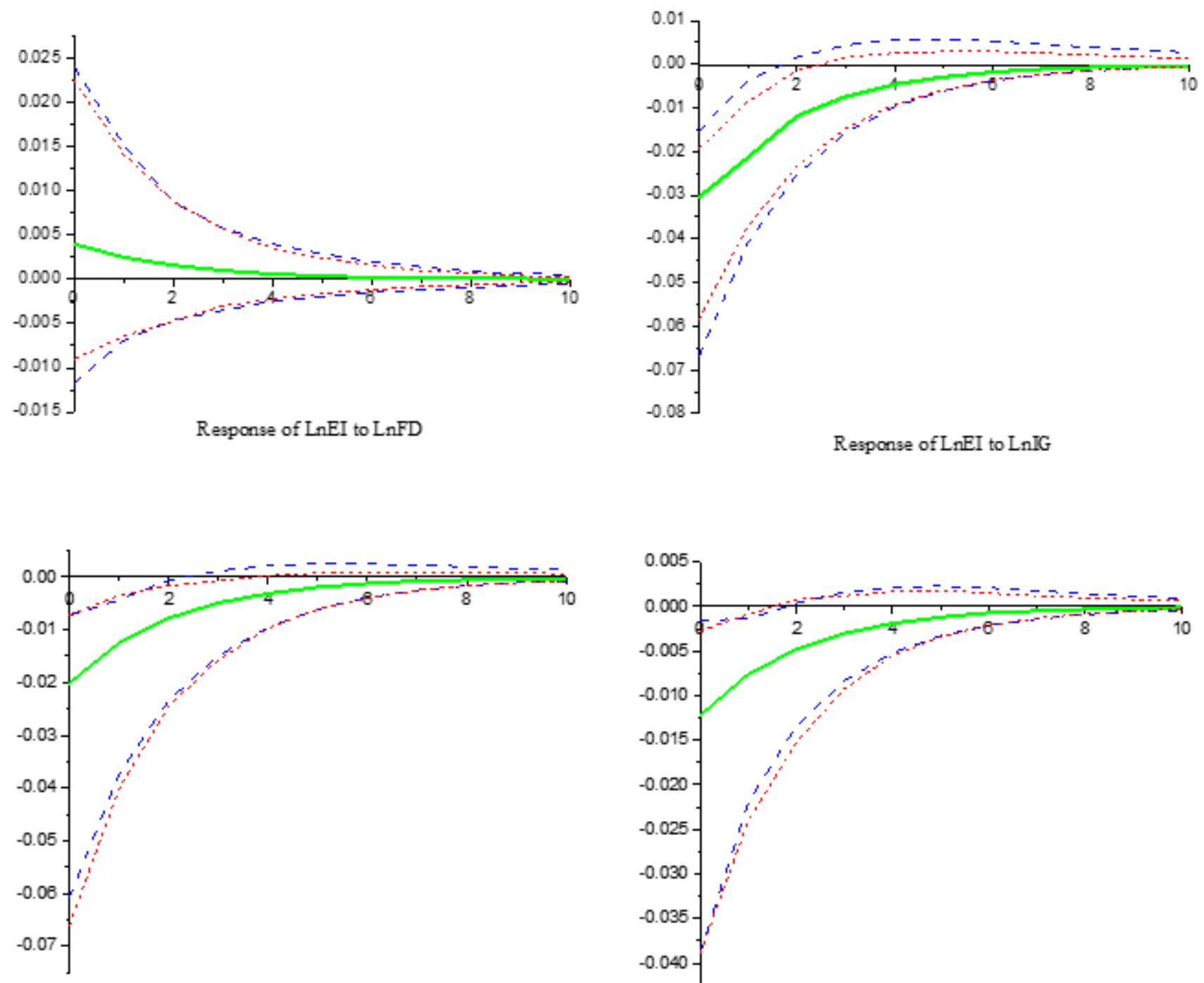

Respone of $\operatorname{LnEI}$ to $\operatorname{LnOR}$

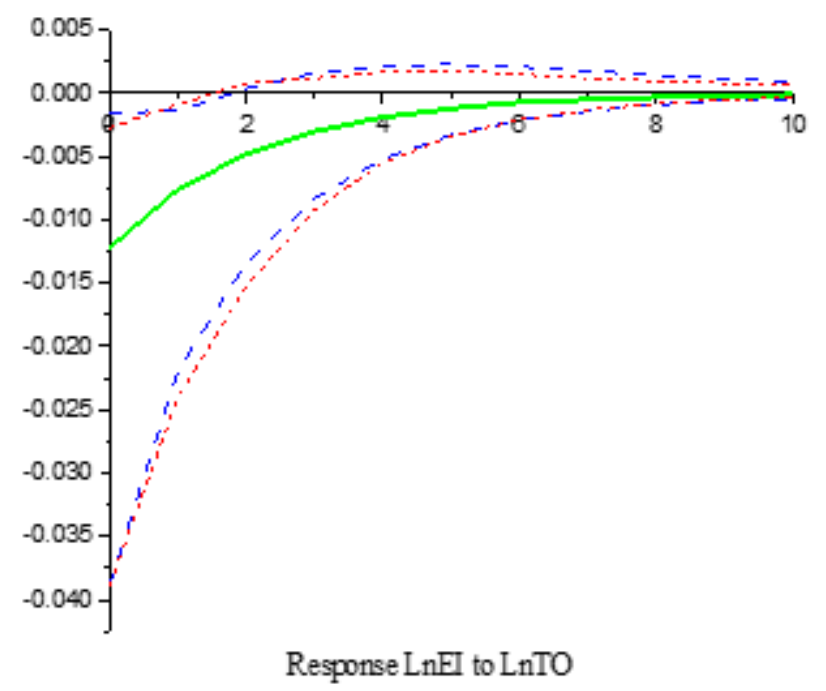

Figure 4

Structural Impulse Responses of LnEl to LnFD, LnIG, LnOR, and LnTO shocks 


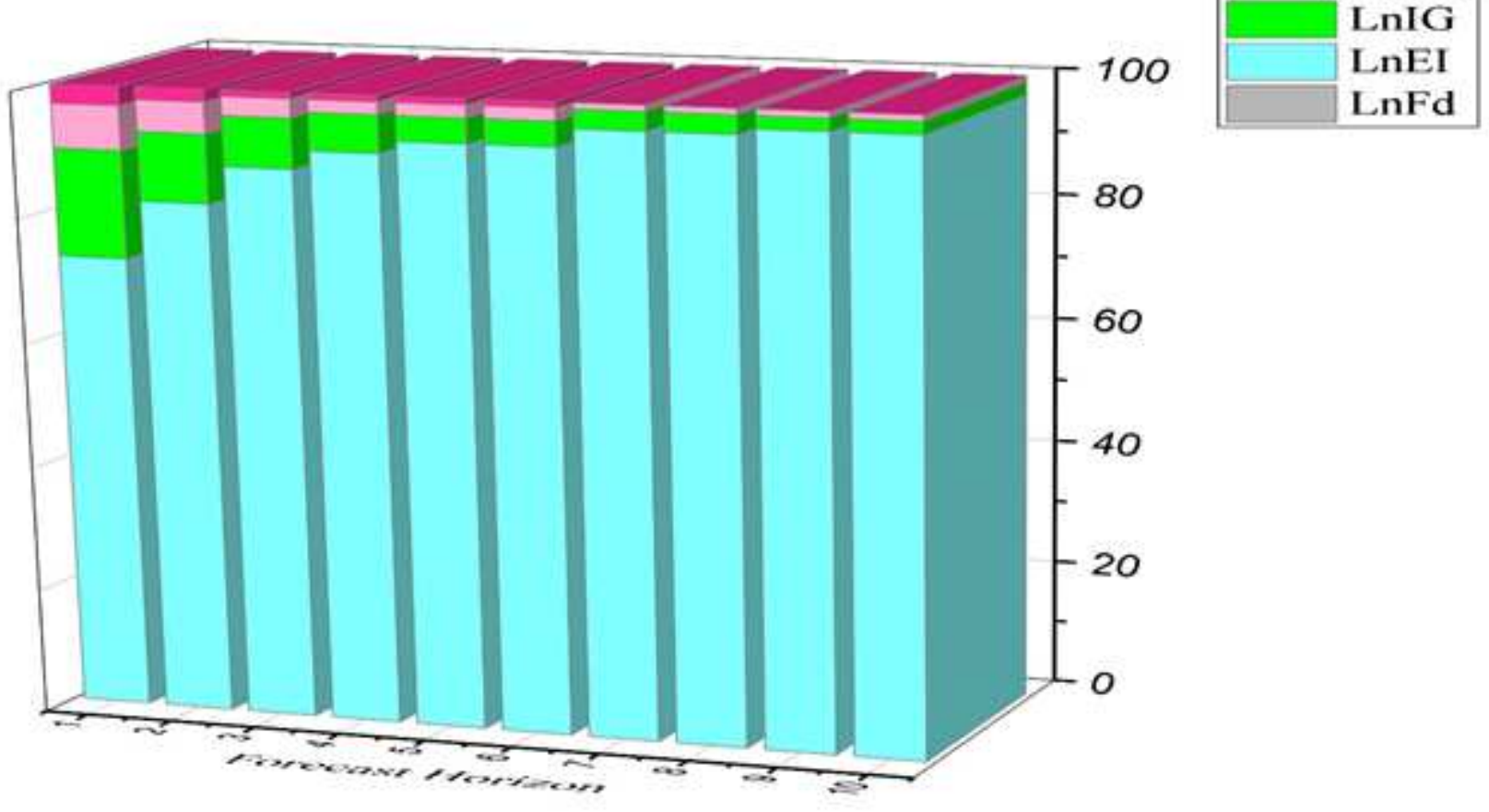

Figure 5

Variance decomposition of energy intensity 